\title{
YREE scavenging in seawater:
}

\section{A new look at an old model}

\author{
Johan Schijf*¹, Emily A. Christenson ${ }^{1}$, \\ and Robert H. Byrne ${ }^{2}$ \\ ${ }^{1}$ University of Maryland Center for Environmental Science, Chesapeake Biological Laboratory, \\ P.O. Box 38, Solomons, MD 20688, USA. \\ ${ }^{2}$ University of South Florida, College of Marine Science, $1407^{\text {th }}$ Avenue South, Saint Petersburg, FL 33701, USA. \\ *Corresponding author. Tel.: +1-410-326-7387; \\ FAX: +1-410-326-7341; e-mail: schijf@cbl.umces.edu
}

(Submitted to Marine Chemistry Special Issue: Cycles in the Ocean)

No part of this manuscript may be cited without consent of the authors 
Abstract. In the ocean, yttrium and the rare earth elements (YREEs) show nutrient-like vertical profiles. Since the YREEs have no manifest biological function, their removal from solution (scavenging) is probably caused by sorption on particles rather than active microbial uptake, yet the exact nature of these particles is uncertain. An existing theoretical model describes scavenging as an equilibrium between complexation with dissolved inorganic ligands and with functional groups on particle surfaces. This model was able to predict input-normalized (i.e., shale-normalized) YREE abundance patterns in seawater without requiring poorly known parameters like particle concentrations or the site densities of functional groups. Employing well-established stabilities of inorganic YREE complexes, while assuming that the sorbent particles are organic with functional groups represented by a mixture of simple monocarboxylic acids, it reproduced some key features of seawater YREE patterns, specifically the characteristic increase of shale-normalized abundance with atomic number and distinctive anomalies of certain trivalent REEs (La and Gd). The familiar negative Ce anomaly of seawater, however, is due to redox reactions that were not explicitly accounted for.

In this study, we refined calculations of YREE solution speciation by adding complexation with desferrioxamine B to gauge the influence of strong organic ligands prevalent near the ocean surface. The scavenging model was then inverted by subtracting high-quality YREE abundance patterns, reported for the open ocean, from this solution speciation to yield an average pattern of relative YREE affinities for the sorbent particles. The resulting affinity pattern is compared with patterns of distribution coefficients, derived from laboratory experiments, for YREE sorption on relevant solid phases including hydrated Fe and Mn oxides (HFO/HMO), calcite, and the green macroalga Ulva lactuca as a substitute for marine organic matter. For deep seawater, the best agreement is observed with HMO, which may thus be the dominant carrier of YREEs to the sediment. Since Ce is catalytically oxidized on manganese oxide surfaces, this could have implications for the evolution of the Ce anomaly. Direct comparisons of distribution coefficient patterns with YREE analyses of suspended particles from the Atlantic Ocean also favor HMO, but this may be dictated in one case by the use of a selective leaching method. For shallow seawater, particularly in the Atlantic Ocean, the best agreement is observed with $U$. lactuca and calcite, although the latter is offset by the low YREE contents of this biogenic mineral. Matches with HFO are generally less convincing. The aforementioned mixture of simple monocarboxylic acids is not a good proxy for the sorptive properties of marine organic matter. 


\section{Introduction}

Vertical profiles of the dissolved concentrations of many trace metals in seawater, including yttrium and the rare earth elements (YREEs), are called nutrient-like, referring to the behavior of nitrate, phosphate, and silicate (Bruland, 1983; Byrne, 2002). In the euphotic zone, nutrients are assimilated by phytoplankton, which subsequently sinks and is remineralized by bacteria who release them back into solution, resulting in concentrations that stay low near the ocean surface but increase rapidly with depth. The vertical profiles of some trace metals show remarkable correlations with specific nutrients, suggesting close associations with the microbial cycle of growth and decomposition. Correlations of Zn and the YREEs with silicate (Bruland et al., 1978; Elderfield, 1988) might be construed as evidence of incorporation into biogenic opal, however high-resolution synchrotron X-ray fluorescence (SXRF) elemental maps of individual diatom cells reveal that Zn and Si are not co-located (Nuester et al., 2012). The puzzling correlation of Cd, which is toxic to most living things, with phosphate (de Baar et al., 1994) became somewhat less so when Lee et al. (1995) demonstrated that it is capable of replacing $\mathrm{Zn}$ as a co-factor of the enzyme carbonic anhydrase under Zn-deficient conditions. The YREEs were recently found to replace $\mathrm{Ca}$ as a co-factor of the enzyme methanol dehydrogenase in unusual hyperacidophilic methanotrophic bacteria (Pol et al., 2014), but such a biological function has not been observed for any marine organism. Microbial uptake of $\mathrm{Zn}, \mathrm{Cd}$, and other micronutrient metals may hinge on extensive complexation with unidentified organic ligands (Jakuba et al., 2012; Baars et al., 2014), yet while the YREEs could be up to 30\% organically complexed (Christenson and Schijf, 2011), similar levels have been observed for Pb (Capodaglio et al., 1990), a toxic metal that does not display nutrient-like distributions (Biller and Bruland, 2012). It appears that the YREEs, along with Sc, Ti, Zr, and Hf (Byrne, 2002), form a separate category of ostensibly non-essential (albeit non-toxic) metals whose vertical profiles are nevertheless distinctly nutrient-like (Fig. 1).

The emergent oceanic distributions of trace metals may have more to do with their reactivity, whereby highly reactive metals (e.g., Mn, Sn) are strongly scavenged and unreactive metals i.e., those that exist as large, single-charged cations (e.g., Cs, Tl), or oxyanions (e.g., Mo, Re), are conservative. The majority of metals is moderately reactive, leading to intermediate, nutrient-like behavior (Byrne, 2002). The sorption processes that underlie metal scavenging in seawater are fundamentally due to the formation of complexes with functional groups that are tightly bound to 
particle surfaces. For mineral particles, like the oxides of silicon, iron, and manganese, these functional groups are hydroxyls, whereas for organic matter additional oxygen-bearing groups are involved, such as carboxyl and phosphoryl, although nitrogen- and sulfur-bearing groups may play a sizeable role as well (Gonzalez-Davila et al., 1995; Zoll and Schijf, 2012). At the pH of seawater, many of these groups are deprotonated and carry negative charge, imparting an electrostatic attraction to the positive metal ion. The primary interaction is with the free, hydrated metal cation and the sorption process is therefore in direct competition with metal complexation in solution. Solution complexation greatly diminishes the inherently high reactivity of the relatively small, trivalent YREE cations and it seems that marine microbes can similarly exert significant control over the reactivity of essential (or toxic) metals by producing strong chelators. Inorganic solution speciation in seawater is fairly easy to model, as most metals form complexes with a limited number of major anions, notably chloride, sulfate, and carbonate, whose stability constants have been carefully measured (Turner et al., 1981; Byrne et al., 1988). The identities of perhaps hundreds of organic ligands that dominate the solution speciation of various trace metals remain elusive, but voltammetric techniques allow at least their total concentrations and conditional stability constants to be determined (Pižeta et al., 2015). A much greater challenge is our scant knowledge of the sorbent particles, for example their bulk concentrations and surface areas, as well as intrinsic properties like the diversity, structures, and site densities of their functional groups.

The scavenging model of Byrne and Kim (1990) was built on an equilibrium between metal complexation with functional groups on particle surfaces (sorption) and with dissolved ligands (desorption). These authors realized that, unlike any single metal, the chemical coherence of the lanthanide series permits YREE scavenging to be modeled in a relative sense, eliminating several unknown parameters. Equally beneficial was an already advanced understanding of their solution speciation in seawater (Byrne and Sholkovitz, 1996). Byrne and Kim (1990) only needed an estimate of YREE affinity for the sorbent particles, which they assumed to be organic, based on a prolific microbial source and ubiquitous presence as reactive coatings on mineral surfaces. They consequently proposed that the main functional group can be represented by a mixture of fifteen randomly selected simple monocarboxylic acids. The model reproduced some key features of shale-normalized seawater YREE patterns, still measured at the time via Instrumental Neutron Activation Analysis (INAA), such as their positive slopes and minor anomalies of La and Gd, yet 
without better information this exercise could be carried no further. In the present study, we utilize complete, high-quality seawater YREE patterns that have since become available through the development of inductively coupled plasma mass spectrometry (ICP-MS). Organic YREE complexation, which Christenson and Schijf (2011) inferred to be subsidiary but not negligible, is added to the solution speciation. While marine particulate matter continues to be inadequately characterized, we now have, from laboratory experiments, distribution coefficient patterns for YREE sorption on a few relevant solid phases: hydrated iron oxide (HFO), hydrated manganese oxide (HMO), calcite, and macroalgal tissue. Rather than guess the nature of marine particulate matter, we construct an average pattern of relative YREE affinities by inverting the scavenging model of Byrne and Kim (1990) in order to assess, by pairwise comparisons with the distribution coefficient data, which solid phases best match its sorptive properties.

\section{The modified equilibrium model for YREE scavenging in seawater}

In the original model (hereafter called the B\&K model), scavenging is envisioned as an equilibrium partitioning of each YREE between the solution and filterable particles where, in the notation of Byrne and Kim (1990), the total YREE concentration in seawater, $A_{M}$, is equal to:

$$
A_{M}=M_{S}+M_{T},
$$

$\mathrm{M}_{\mathrm{S}}$ being the particulate YREE concentration and $\mathrm{M}_{\mathrm{T}}$ the total dissolved YREE concentration (both in mol/L). Byrne and Kim (1990) named the concentration of particles $\phi_{\mathrm{P}}($ in $\mathrm{g} / \mathrm{L}$ ), so that the particulate YREE concentration in units of mol per $g$ of particles is $M_{P}=M_{S} / \phi_{P}$. The YREE solid-solution distribution coefficient, $\mathrm{D}_{\mathrm{M}}$, was subsequently defined as:

$$
\mathrm{D}_{\mathrm{M}}=\frac{\mathrm{M}_{\mathrm{P}}}{\mathrm{M}_{\mathrm{T}}}=\frac{\mathrm{M}_{\mathrm{S}} / \phi_{\mathrm{P}}}{\mathrm{M}_{\mathrm{T}}} .
$$

If we view YREE scavenging in the ocean in terms of a steady-state, single-box model (Schindler, 1975) then the flux of particles out of this box and into the sediment can be written as $F_{P}=\phi_{P} / \tau_{P}$, where $\tau_{\mathrm{P}}$ is the particle residence time. This particle flux is the only means by which YREEs are removed from the box, with a concomitant metal flux 


$$
\mathrm{F}_{\mathrm{M}}=\mathrm{F}_{\mathrm{P}} \times \mathrm{M}_{\mathrm{P}}=\mathrm{F}_{\mathrm{P}} \times \frac{\mathrm{M}_{\mathrm{S}}}{\phi_{\mathrm{P}}}=\frac{\mathrm{M}_{\mathrm{S}}}{\tau_{\mathrm{P}}}
$$

The metal flux can also be written per definition as $F_{M}=A_{M} / \tau_{M}$, where $\tau_{M}$ is the YREE residence time with respect to scavenging. Using Eqs. 1-3, it follows that

$$
\tau_{M}=\tau_{P} \times \frac{A_{M}}{M_{S}}=\tau_{P} \times \frac{M_{S}+M_{T}}{M_{S}}=\tau_{P} \times\left(1+\frac{M_{T}}{M_{S}}\right)=\tau_{P}\left(1+\phi_{P}^{-1} D_{M}^{-1}\right) \approx \tau_{P} \phi_{P}^{-1} D_{M}^{-1},
$$

since $\tau_{M} \square \tau_{P}$ for the YREEs, which have oceanic residence times on the order of hundreds of years or longer (Nozaki and Alibo, 2003b). From the basic definition of residence time

$$
\tau_{\mathrm{M}}=\frac{\mathrm{A}_{\mathrm{M}}}{\left(\mathrm{dA}_{\mathrm{M}} / \mathrm{dt}\right)}
$$

Byrne and Kim (1990) argued that $\tau_{M}$ (i.e., the term $\tau_{P} \phi_{P}^{-1} D_{M}^{-1}$ ), when plotted on a logarithmic scale, should resemble shale-normalized YREE abundance patterns in seawater, because relative steady-state YREE inputs into the global ocean are commonly assumed to have a shale-like source signature (Elderfield, 1988).

The YREE residence time can be quantified in terms of the stability of YREE complexes with dissolved ligands $L_{j}$ and functional groups $S_{i}$ :

$\tau_{M}=\tau_{P} \phi_{P}^{-1} D_{M}^{-1}=\tau_{P} \times \frac{M_{T}}{M_{S}}=\tau_{P} \times \frac{M_{T} /[M]}{M_{S} /[M]}=\tau_{P} \times \frac{\sum_{j, n}\left(1+{ }_{j} \beta_{n}\left[L_{j}\right]\right)}{\sum_{i}\left({ }_{i} K_{S} \times\left[\equiv S_{i}\right]\right)}$,

where $[M]$ is the free dissolved YREE concentration and the stability constant ${ }_{j} \beta_{n}$ for the $n^{\text {th }}$ YREE complex with dissolved ligand $\mathrm{L}_{\mathrm{j}}$ is defined as: 


$$
\mathrm{M}^{3+}+\mathrm{nL}_{\mathrm{j}}^{\mathrm{z}-} \square \mathrm{M}\left(\mathrm{L}_{\mathrm{j}}\right)_{\mathrm{n}}^{3-\mathrm{nz}} \quad{ }_{\mathrm{j}} \beta_{\mathrm{n}}=\frac{\left[\mathrm{M}\left(\mathrm{L}_{\mathrm{j}}\right)_{\mathrm{n}}\right]}{[\mathrm{M}]\left[\mathrm{L}_{\mathrm{j}}\right]^{\mathrm{n}}} .
$$

The stability constant ${ }_{i} K_{S}$ for a YREE complex with functional group $S_{i}$ is defined as:

$$
\mathrm{M}^{3+}+\equiv \mathrm{S}_{\mathrm{i}}^{\mathrm{z}-} \square \equiv \mathrm{S}_{\mathrm{i}} \mathrm{M}^{3-\mathrm{z}} \quad{ }_{\mathrm{i}} \mathrm{K}_{\mathrm{S}}=\frac{\left[\equiv \mathrm{S}_{\mathrm{i}} \mathrm{M}\right]}{[\mathrm{M}]\left[\equiv \mathrm{S}_{\mathrm{i}}\right]},
$$

where $\mathrm{M}_{\mathrm{S}}=\sum_{\mathrm{i}}\left[\equiv \mathrm{S}_{\mathrm{i}} \mathrm{M}\right]$ and the triple-bond signs indicate that the functional group $\mathrm{S}_{\mathrm{i}}$ and the complex $\mathrm{S}_{\mathrm{i}} \mathrm{M}$ are tightly bound to a particle surface.

For the solution speciation, Byrne and Kim (1990) included YREE monocarbonato- and dicarbonato-complexes (with one and two carbonate anions), as well as chloride, fluoride, sulfate and hydroxide complexes, as reported by Stanley and Byrne (1990). For surface complexation, they assumed that marine particles are overwhelmingly organic, containing a single type of functional group whose stability constant, $\log \overline{\mathrm{K}}_{\mathrm{S}}$, was taken as the mean of fifteen randomly selected simple monocarboxylic acids. Combining Eqs. 5 and 6 in logarithmic form yields:

$$
\log \frac{A_{M}}{\left(d A_{M} / d t\right)}=\log \left(\sum_{j, n}\left(1+{ }_{j} \beta_{n}\left[L_{j}\right]\right)\right)-\log \bar{K}_{S}+\log \left(\frac{\tau_{P}}{\sum_{i}\left[\equiv S_{i}\right]}\right)
$$

In the following, we will refer to the term on the left as the abundance term, or A-term, and the first term on the right as the ligand term, or L-term. The third term on the right contains the ratio of the particle residence time, $\tau_{\mathrm{P}}$, and the sum concentration (total site density) of all functional groups, $\mathrm{S}_{\mathrm{i}}$. Both parameters are particle properties and independent of the sorbed metal, hence the third term is a constant that has the same value for all YREEs and does not affect their relative behavior. Byrne and Kim (1990) were thus able to calculate the A-term by ignoring this constant and to compare it with the best seawater YREE patterns available at the time. Here, we rearrange Eq. 8 as follows: 
$\log \bar{K}_{S}=\log \left(\sum_{j, n}\left(1+{ }_{j} \beta_{n}\left[L_{j}\right]\right)\right)-\log \frac{A_{M}}{\left(d_{A} / d t\right)}(+$ constant $)$,

to calculate $\log \overline{\mathrm{K}}_{\mathrm{S}}$, which we compare with distribution coefficients for YREE sorption on relevant solid phases. For the L-term we do not consider YREE complexes with fluoride, which are negligible, but add complexation with strong organic ligands, represented by the siderophore desferrioxamine B (DFOB), which may constitute as much as 30\% of total dissolved YREE concentrations near the ocean surface (Christenson and Schijf, 2011). Stability constants for YREE complexes with inorganic ligands are updated with the latest literature values. For the A-term we substitute complete, high-quality seawater YREE patterns from the Atlantic Ocean (Osborne et al., 2015) and the Pacific Ocean (Zhang and Nozaki, 1996), measured via ICP-MS.

\section{Results and discussion}

\subsection{YREE solution speciation in seawater}

To derive the L-term of our modified scavenging model (Eq. 9), YREE solution speciation in seawater was calculated in two steps, using MINEQL2.0 (Westall et al., 1986). In the first step, solution speciation of the major cations and anions was calculated for a standard seawater sample of salinity $\mathrm{S}=35$. Major cations and anions considered were $\mathrm{Na}^{+}, \mathrm{K}^{+}, \mathrm{Mg}^{2+}$, and $\mathrm{Ca}^{2+}$, chloride $\left(\mathrm{Cl}^{-}\right)$, sulfate $\left(\mathrm{SO}_{4}^{2-}\right)$, carbonate $\left(\mathrm{CO}_{3}^{2-}\right)$, hydroxide $\left(\mathrm{OH}^{-}\right)$, and borate $\left(\mathrm{B}(\mathrm{OH})_{4}^{-}\right)$. Although fluoride ( $\mathrm{F}^{-}$) forms ion pairs with $\mathrm{Mg}^{2+}$, its concentration in seawater is low ( $\sim 68 \mu \mathrm{mol} / \mathrm{kg}$; Byrne, 2002) and its contribution to YREE solution speciation negligible. It was therefore omitted from the calculations. Ion-pairing constants for these components were mostly taken from Millero and Schreiber (1982) and are listed in Table 1. Protonation constants for carbonate were taken from Luo and Byrne (2004) and converted to the free-ion concentration scale. The ionization constant of water was taken from Christenson and Schijf (2011). The protonation constant for borate was taken from Byrne and Kester (1974), as were constants for its ion pairs with the major cations, except $\mathrm{K}^{+}$.

Speciation calculations were executed at a fixed $\mathrm{pH}$ of 8.33 on the free-ion concentration scale, equivalent to 8.2 on the total scale. Before every iteration, MINEQL normally extrapolates the stability constants stored in its standard thermodynamic database (valid at $\mathrm{I}=0$ ) to the ionic 
strength of the solution, using the Davies Equation. To ensure application of the most accurate values appropriate to seawater $(I=0.7)$, this extrapolation, which is less reliable for $I>0.5$, was disabled by fixing the ionic strength at zero, after customizing the database with the constants from Table 1. Precipitation of solids and gas exchange with the atmosphere were also disabled. The results (not shown) are in good agreement with speciation calculations for standard seawater reported in the literature (e.g., Millero and Schreiber, 1982; Byrne, 2002).

In the second step, YREEs were added to the seawater speciation model. Only La and Ce are part of the MINEQL database, from which we eliminated their higher-order complexes with chloride and hydroxide. Others were added, such as the dicarbonato-complex. The database was supplemented with the latest literature values for YREE complexation in seawater (Table 2). Stability constants for chloride and sulfate complexes were taken from Luo and Byrne (2001) and Schijf and Byrne (2004), respectively, and first hydrolyis constants (log $\beta_{1}^{*}$ ) from Klungness and Byrne (2000). Constants for mono- and dicarbonato-complexes and complexes with bicarbonate $\left(\mathrm{HCO}_{3}^{-}\right)$were taken from Luo and Byrne (2004) and converted to the free-ion concentration scale. The limited number of slots available for extra cations or ligands forced a division of the YREEs into three groups: Y + LREEs (La, Ce, Pr, Nd); La + MREEs (Sm, Eu, Gd, Tb, Dy); and La + HREEs (Ho, Er, Tm, Yb, Lu). For convenience, total dissolved YREE concentrations, $\mathbf{M}_{\mathrm{T}}$, were fixed at $1 \mathrm{pmol} / \mathrm{kg}$. Even in actual seawater, where $\mathbf{M}_{\mathrm{T}}$ ranges from 1 to $<100 \mathrm{pmol} / \mathrm{kg}$ (Elderfield, 1988), most ligands (viz. the major anions) are too abundant to be affected by YREE complexation, or otherwise we held their free concentration constant (Section 3.2). This renders $\log M_{T} /[M]$, the ratio of the total dissolved and free YREE concentrations i.e, the L-term, which depends solely on free ligand concentrations (Eq. 6), insensitive to the value of $\mathrm{M}_{\mathrm{T}}$ and it also justifies our involuntary calculation of the YREE speciation in three groups, as evidenced by identical results obtained for the shared element La.

The inorganic solution speciation of the YREEs in seawater at $\mathrm{S}=35$ and $\mathrm{pH} 8.2$ is given in Table 3, where species contributions are expressed as a percentage of the total dissolved YREE concentration. Percentages are rounded to one decimal place, hence contributions smaller than 0.05\% are not recorded. For all YREEs, a majority of the total dissolved concentration (>89\%) consists of complexes with carbonate. For La, the monocarbonato-complex comprises about 52\% and this contribution decreases with atomic number in favor of the dicarbonato-complex, which comprises about $88 \%$ for Lu. The two species are about equally abundant for Pr. Contributions 
of complexes with the other major anions are minute, some as high as about $5 \%$ but typically less than $1 \%$. The contribution of the free hydrated cation, which is most pertinent here, gradually declines with atomic number from $4.8 \%$ for La to less than $0.1 \%$ for Lu. Agreement with YREE speciations reported by Byrne et al. (1988) and Byrne and Sholkovitz (1996) is qualitatively good. Quantitative discrepancies are likely caused by slight variations in the major ion speciation or their use of marginally different conditions and stability constants that were modeled or not measured at the right ionic strength. Specifically, our calculations yield a larger contribution of the hydroxide complex, especially for HREEs, presumably reflecting more accurate stability constants for YREE complexes with hydroxide and carbonate (Table 2) that were not available to Byrne and Sholkovitz (1996). Comparison with an earlier YREE speciation reported by Turner et al. (1981) is hindered by the fact that they did not consider the important dicarbonato-complex.

Table 3 also lists values of the L-term (Eq. 9). The corresponding pattern is plotted in Figure 2 , rising gradually with atomic number and displaying a pronounced negative Gd anomaly plus two faint 'M-shaped tetrads' (Monecke et al., 2002), for Gd-Ho and Er-Lu. The value for Y is approximately equal to that for Eu. Figure 2 moreover shows patterns for $\mathrm{pH} 7.8$ and 7.4 (total scale), which may represent YREE speciations for deep seawater, or for seawater affected by progressive ocean acidification (e.g., Feely et al., 2004). Byrne et al. (1988) reported values of $\log \mathrm{M}_{\mathrm{T}} /[\mathrm{M}]$ at $\mathrm{pH} 8.2$ and $\mathrm{pH} 7.6$ that are $0.1-0.2$ units lower on average than ours, but 0.1-0.2 units higher for $\mathrm{Y}$ and La, leading to L-term patterns that have nearly the same slopes as those in Figure 2, but lack their subtle structure due to the use of interpolated stability constants.

\subsection{The potential importance of YREE complexation with strong organic ligands}

Turner et al. (1981) suggested that elements with a particular affinity for both carbonate and hydroxide may also have a strong tendency to form organic complexes. It is presently unclear what organic ligands might be involved in these complexes. Although stability constants have been measured for YREE complexes with numerous small organic ligands (Martell et al., 2004), many of these are relatively weak or not sufficiently abundant in seawater to alter YREE solution speciation. Christenson and Schijf (2011) recently showed that hexadentate YREE complexes with desferrioxamine B (DFOB), a model hydroxamate siderophore, are 3-4 orders of magnitude more stable than their dicarbonato-complexes and, under favorable conditions, may constitute a significant fraction of total HREE concentrations. Hydroxamate siderophores are probably not 
the most abundant organic ligands in seawater (Vraspir and Butler, 2009), but they are common (Trick, 1989) and compounds in the desferrioxamine family have been detected at low-picomolar concentrations throughout the surface ocean (Mawji et al., 2008). While highly specific to $\mathrm{Fe}^{3+}$, siderophores can form complexes with many metal cations and may well affect or even dominate their speciation and reactivity in seawater (Butler, 1998; Butler and Theisen, 2010). Another class of ligands likely to be important for YREE speciation are humic acids, however most investigations of YREE-humate complexation have focused on terrestrial systems (e.g., Davranche et al., 2004, 2008; Pourret et al., 2007; Pourret and Martinez, 2009), and their abundance and chemical behavior in the ocean are still largely unexplored.

In order to gauge the potential influence of organic complexation on YREE scavenging in seawater we expanded our MINEQL speciation model with DFOB to represent a strong organic ligand (Table 2). Since the exact concentrations and speciation of siderophores in seawater are not known, we controlled the extent of organic complexation by fixing the free concentration of the single-protonated ligand, $\mathrm{HL}^{2-}$, the species that forms the most stable YREE complexes (where $\mathrm{L}^{3-}$ stands for fully deprotonated DFOB). Christenson and Schijf (2011) showed that DFOB complexes may contribute up to about $30 \%$ of the total Lu concentration in seawater. The free ligand concentration was thus adjusted to yield 30\%, and also 10\%, Lu complexation with DFOB at $\mathrm{pH}$ 8.2. The solution speciation of all other YREEs was then recalculated under those conditions, keeping the free ligand concentration fixed at the correct levels, which are $\sim 0.7 \times 10^{-13}$ and $\sim 2.8 \times 10^{-13} \mathrm{M}$, respectively. It should be noted that, due to competition with other trace metals and possibly with $\mathrm{Mg}^{2+}$ and $\mathrm{Ca}^{2+}$ (Wuttig et al., 2013), it would require an unrealistically high DFOB concentration to produce these conditions, yet we emphasize here as we have before (Christenson and Schijf, 2011; Schijf et al., 2015) that DFOB embodies a broader class of strong organic ligands that, in total, is much more abundant than hydroxamate siderophores alone.

The rather modest effect of the siderophore is shown in Figure 2 and mainly restricted to the HREEs. Even at 30\% Lu-DFOB complexation, the speciation of Y and La-Gd remains largely unchanged. Values of the L-term, $\log \mathrm{M}_{\mathrm{T}} /[\mathrm{M}]$, are raised for elements heavier than Gd and deviations increase gradually with atomic number. The net effect is more HREE fractionation relative to the LREEs. The effect on Ce could not be determined because rapid oxidation of Ce(III) by the ligand prevented Christenson and Schijf (2011) from measuring the stabilities of its DFOB complexes. However, in accordance with the behavior of neighboring elements La and 
Pr, it should be negligible. At 10\% Lu-DFOB complexation, the effect is the same but less pronounced. As the three lowest acid dissociation constants of DFOB are in the $\mathrm{pH}$ range 8.5-9.7 (Christenson and Schijf, 2011), the ligand quickly protonates below pH 8.2 and its influence on YREE solution speciation wanes. These calculations were therefore not repeated at lower $\mathrm{pH}$.

We stated in Section 1 that the identities of strong organic ligands in seawater are largely unknown. Nonetheless, the effect in Figure 2 is arguably typical for a variety of conceivable candidates. Figure 3 compares the dicarbonato-complexes, which dominate inorganic YREE speciation in seawater, with hexadentate DFOB-complexes, hexadentate EDTA-complexes, and complexes with the phenolic sites of terrestrial humic acid. Despite stability constants that span 8 orders of magnitude, the four patterns are resemblant, with values increasing from $\mathrm{La}$ to $\mathrm{Lu}$, a negative Gd anomaly, and Y falling among the MREEs. Their slope seems to be higher for the stronger ligands, but does not increase in a consistent way. Different organic ligands should consequently have a similar effect on the shape of the L-term pattern, although the degree of change will depend on ligand type, strength, and abundance. In summary, we are confident that the pattern for 30\% Lu-DFOB complexation at $\mathrm{pH} 8.2$ (Fig. 2), while perhaps an upperbound scenario, is a reliable estimate of YREE solution speciation near the ocean surface, regardless of the true nature of marine organic ligands.

\subsection{Comparisons of the refined B\&K model with modern shale-normalized YREE patterns}

For their original scavenging model, Byrne and Kim (1990) calculated the A-term on the left-hand side of Eq. 8 and qualitatively compared it with shale-normalized REE patterns from the Pacific Ocean reported by de Baar et al. (1985). These patterns, generated with INAA and missing only the elements $\mathrm{Y}$, Dy, and Er, were the best then available, but their irregular shapes evince the inherently lower accuracy and precision of that technique. The virtually synchronous development of Isotope Dilution-Thermal Ionization Mass Spectrometry (ID-TIMS) (Greaves et al., 1989) and ICP-MS combined with improved extraction methods (Shabani et al., 1992) has enabled superior analyses of the YREEs in seawater. Patterns measured via ID-TIMS, which is all but independent of the extraction efficiency, are highly accurate yet incomplete since the mono-isotopic elements (Y, Pr, Tb, Ho, Tm) cannot be determined (e.g., Piepgras and Jacobsen, 1992). For the present study we preferred patterns measured via ICP-MS which, when combined with a quantitative extraction method, gives excellent data for 14 REEs (except Pm) and Y. For 
almost a decade, such patterns were published predominantly by the group of the late Dr. Nozaki (Nozaki et al., 1997, 1999; Alibo and Nozaki, 1999, 2000; Nozaki and Alibo, 2003a,b; Hongo et al., 2006). The launch of the international GEOTRACES program circa 2010 has resulted in the unification and intercalibration of analytical protocols (Pahnke et al., 2012; van de Flierdt et al., 2012), plus a revived interest in YREE marine geochemistry. A spate of new studies has appeared (e.g., Garcia-Solsona et al., 2014; Haley et al., 2014; Molina-Kescher et al., 2014; Osborne et al., 2014, 2015; Hathorne et al., 2015), but several unfortunately either do not report Y concentrations, or focus entirely on the upper or lower water column.

Because a detailed geographic investigation of YREE scavenging is beyond the scope of this work, we somewhat arbitrarily selected one shallow and one deep sample each from the Atlantic Ocean (Osborne et al., 2015) and the Pacific Ocean (Zhang and Nozaki, 1996). Their YREE patterns, normalized to Post-Archaean Australian Shale (PAAS) (McLennan, 1989), are shown in Figure 4. Being on opposite ends of the Global Conveyor Belt and spanning a large depth range, we contend that these four samples encompass much of the natural variation in seawater pattern shapes (Bertram and Elderfield, 1993). Apart from an order-of-magnitude difference in concentrations, the shallow and deep patterns are similar, albeit the latter have more negative Ce anomalies, de-emphasized here as these cannot be reproduced by the equilibrium scavenging model, and smaller Y enrichments. All display the characteristic increase of shale-normalized abundance with atomic number, however the Atlantic patterns are less fractionated than the corresponding Pacific patterns. A distinct maximum around Er is seen in both shallow patterns and therefore probably real, yet invoking a detailed explanation would be too speculative.

Our initial approach is to refine the B\&K model (Eq. 8) and compare it more directly with these high-quality seawater patterns. For the L-term, we substituted our YREE solution speciations (Fig. 2), which differ from the ones employed by Byrne and Kim (1990) as described in Section 3.1. For the $\log \overline{\mathrm{K}}_{\mathrm{s}}$ term, Byrne and Kim (1990) made some sweeping assumptions. Since the exact nature of marine particles is uncertain, their relative affinity for the YREEs had to be estimated. Particulate organic matter is plentiful near the ocean surface, whereas the sorptive properties of mineral particles are governed by organic coatings (Loder and Liss, 1985; Stanley and Byrne, 1990), hence Byrne and Kim (1990) surmized that most marine particles are essentially organic. It was further assumed that the main functional groups are carboxylic acids, important mediators of YREE sorption on organic matter (Ngwenya et al., 2009; Zoll and Schijf, 
2012), and that YREE complexation with carboxylic acid functional groups is much like solution complexation with carboxylate ligands. They thus selected fifteen monocarboxylic acids from the volumes of Critical Stability Constants (Martell and Smith, 1977, 1982; Smith and Martell, 1989) and calculated average values of $\log _{j} \beta_{1}$ (Eq. $7 \mathrm{a}$ ) for every REE, largely at $\mathrm{I}=0.1$ and $\mathrm{T}=$

$25^{\circ} \mathrm{C}$, to represent $\log \overline{\mathrm{K}}_{\mathrm{S}}$. We recalculated $\log \overline{\mathrm{K}}_{\mathrm{S}}$ from the original data (Byrne and Li, 1995), corrected with revisions from the NIST database (Martell et al., 2004), and added values for Y.

To construct model curves of shale-normalized YREE abundances in shallow and deep seawater, the recalculated $\log \overline{\mathrm{K}}_{\mathrm{S}}$ values were subtracted from our $\log \mathrm{M}_{\mathrm{T}} /[\mathrm{M}]$ values at $\mathrm{pH} 8.2$ (without organic complexation) and $\mathrm{pH}$ 7.6, respectively (Fig. 4). The B\&K model (Eq. 8) is only accurate within a constant identical for all YREEs ( $c f$. Eq. 9), so the curves were vertically shifted to maximize overlap with the average shallow or deep seawater pattern, and yield a more quantitative metric of their comparative agreement. This was accomplished by minimizing the sum-of-squares difference for each pair, obtained from the logarithmic A-term values of all shared YREEs, excluding $\mathrm{Y}$ and Ce whose unique chemistries induce behavior not well correlated with that of the other lanthanides. Average shallow and deep seawater was calculated after matching the Atlantic to the corresponding Pacific patterns in the same manner.

Our model curves have a lot more structure than those reported by Byrne and Kim (1990). They show negative La and Gd anomalies (Fig. 4), deviating markedly from the seawater patterns, as well as insufficient Y fractionation. Contrary to observations, HREE enrichment of the model curves decreases at depth, where the $\mathrm{pH}$ is lower, which is a fundamental flaw. The Ce anomaly is not reproduced for reasons already mentioned. When supplied with the latest stability constants, the scavenging model of Byrne and Kim (1990) is actually less skilled at predicting key features of high-quality seawater YREE patterns from widespread locations and depths, invalidating the premise that carboxylate ligands can emulate the sorptive properties of marine particulate matter. In order to avoid any such conjecture, we constructed model curves of log $\overline{\mathrm{K}}_{s}$ by inverting the B\&K model through a straightforward rearrangement of terms (Eq. 9).

\subsection{Comparisons of the inverted model with distribution coefficients for relevant solid phases}

In recent years, careful laboratory experiments have been conducted to determine distribution coefficients, $\log { }_{i} K_{S}$, for YREE sorption on various pure solid phases, in seawater-like solutions (e.g., $0.5 \mathrm{M} \mathrm{NaCl}$ ). These include hydrated Fe and Mn oxides (Ohta and Kawabe, 2001; Quinn et 
al., 2006b; Schijf and Marshall, 2011; K.S. Marshall, unpubl. data), calcite (Toyama and Terakado, 2014), and the green macroalga Ulva lactuca L. (Zoll and Schijf, 2012), taken as a substitute for marine organic matter. We compare distribution coefficient patterns for each solid phase, chosen at the highest available solution $\mathrm{pH}$ (7.4-8.2), with model curves of log $\overline{\mathrm{K}}_{\mathrm{S}}$, which again were vertically shifted to maximize overlap. Section 4 presents an evaluation of all pairwise comparisons, but here only the best matches in shallow and deep seawater are discussed (Fig. 5). For the blue model curves, shallow Atlantic and Pacific seawater patterns (Fig. 4) were subtracted from the L-term at $\mathrm{pH} 8.2$ with 30\% Lu-DFOB complexation (Fig. 2). For the red model curves, deep seawater patterns (Fig. 4) were subtracted from an L-term at pH 7.6 without organic complexation (not shown), more typical of seawater below $3000 \mathrm{~m}$.

Figures 5A and B reveal that the distribution coefficient patterns for U. lactuca and HFO are similar in shape, especially for $\mathrm{Gd}-\mathrm{Lu}$, and match model curves for shallow seawater much better than for deep seawater. The main reason is the steeper slope of the shallow model curves, which is due to the higher $\mathrm{pH}$ and particularly to YREE complexation with organic ligands (Fig. 2). On the other hand, even the best match, between U. lactuca and shallow Atlantic seawater, shows discrepancies for the MREEs and a pronounced mismatch at Pr-Nd. Figure 5A also confirms that the $\log \bar{K}_{S}$ pattern used in the B\&K model (Section 3.3) is not a good match for $U$. lactuca, in other words for marine organic matter. While it does simulate Y enrichment, the slope is too low and it is too straight, lacking the structure of both our model curves and the distribution coefficient patterns. Whereas the stability constants employed in the calculation of $\log \overline{\mathrm{K}}_{\mathrm{S}}$ mostly apply to $\mathrm{I}=0.1$ (Byrne and $\mathrm{Li}$, 1995), this should not greatly affect its pattern. More likely the functional groups of marine organic matter are not well represented by a mixture of simple monocarboxylic acids, or the ones chosen are not the most suitable, given that individual ligands in the mixture show a wide range of behaviors (Byrne and Kim, 1990).

Figure 5C shows that the distribution coefficient pattern for HMO is in excellent agreement with the model curve for deep Pacific seawater, suggesting it to be the primary YREE scavenger in the abyssal ocean. The better match than for shallow seawater in this case results mainly from the smaller slope between Er and Lu, caused by the absence of organic complexation. A minor mismatch occurs at La, but the Pacific model curves do reproduce its enrichment relative to $\mathrm{Y}$, not observed for U. lactuca and HFO (Figs. 5A and B). The large positive Ce anomaly in the distribution coefficient pattern reflects the fact that $\mathrm{Ce}$ is catalytically oxidized on manganese 
oxide surfaces (Ohta and Kawabe, 2001; Davranche et al., 2005, 2008; K.S. Marshal, unpubl. data), which could partly explain the large negative Ce anomalies of deep seawater (Fig. 1).

A number of experimental studies have addressed YREE partitioning from seawater into calcite, but oceanic conditions were approximated most closely (0.68 M NaCl, 2 mM Ca, 20-30 pM REE, pH 8.4-8.5) in the novel study of Toyama and Terakado (2014). Unfortunately, REE concentrations were measured via ID-TIMS so the partition coefficient patterns are incomplete. Terakado and Masuda (1988) conducted their experiments at lower ionic strength. They also used YREE concentrations that were 3-4 orders of magnitude higher, as did Zhong and Mucci (1995), Tanaka et al. (2004), and Tanaka and Kawabe (2006). The latter two papers contain complete patterns measured via ICP-MS at pH 6.6 and YREE concentrations of 60-120 nM in solutions of near-seawater ionic strength, yet different composition (0.2 $\left.\mathrm{M} \mathrm{CaCl}_{2}, 0.05 \mathrm{M} \mathrm{NaCl}\right)$.

In all five studies, the partition coefficients were defined in terms of total dissolved YREE concentrations. We converted these to distribution coefficients for comparison with our model curves, using $\log \mathrm{M}_{\mathrm{T}} /[\mathrm{M}]$ values derived from MINEQL calculations of YREE speciation for the exact solution compositions given by Tanaka and Kawabe (2006) and Toyama and Terakado (2014). The distributions coefficients include normalization to Ca and are therefore assigned the symbol $\mathrm{D}_{\mathrm{Ca}}$ and not ${ }_{\mathrm{i}} \mathrm{K}_{\mathrm{Ca}}$ (Fig. 5D). It should be noted that Toyama and Terakado (2014) also recalculated the YREE solution speciation of Tanaka and Kawabe (2006) and found it to be dominated by the free cation and not the monocarbonato-complex as the authors had proposed. Our own recalculation is somewhere in between, with the free cation dominating for $\mathrm{La}-\mathrm{Nd}$ and the monocarbonato-complex for the others REEs. The ICP-MS analyses of YREE sorption on calcite in artificial seawater by Zhong and Mucci (1995) could not be so converted, because the fixed but variable pH of their solutions was not reported. Haley et al. (2005) calculated partition coefficients for biogenic calcite by normalizing their ID-TIMS analyses of the REE contents of a planktic foraminifer (Neogloboquadrina dutertrei), collected from sediment core tops, to REE concentrations in shallow seawater reported for nearby stations. We converted these to distribution coefficients using our YREE solution speciation at $\mathrm{pH} 8.2$ (Fig. 2). The resulting pattern is remarkably similar to that of Toyama and Terakado (2014) and model curves are compared with the average of the two.

Figure 5D shows that the model curve for shallow Atlantic seawater is in reasonable agreement with the average of the patterns of Haley et al. (2005) and Toyama and Terakado 
(2014), although its slope is too small between La and Gd. Conversely, the model curve for deep Pacific seawater is a surprisingly good match for the pattern of Tanaka and Kawabe (2006), on par with HMO (Fig. 5C). This is probably fortuitous and certainly counterintuitive, because their experimental conditions ( $\mathrm{pH}$ 6.6, $0.2 \mathrm{M} \mathrm{CaCl}_{2}, 60-120 \mathrm{nM}$ YREEs) are much less seawater-like and calcite does not persist in the deep ocean, especially in the Pacific where the lysocline occurs higher in the water column. The agreement of calcite with shallow Atlantic seawater appears comparable to that of $U$. lactuca and HFO (Figs. 5A and B), yet the importance of biogenic calcite as a YREE scavenger is offset by its low contents (Roberts et al., 2012). Martínez-Botí et al. (2009) found that the elevated YREE (Nd) contents of planktic foraminifera are associated with occluded organic tissue that is resistant to chemical cleaning and not with the calcite test or Fe-Mn oxide coatings. They argued that the strong correlation between foraminiferal YREE and Mn contents reflects a similar association of Mn with the occluded organic tissue.

Two important solid phases not considered here are biogenic silica (opal) and authigenic clay minerals. Whereas there seem to be few laboratory studies of YREE sorption on hydrated silica (Byrne and Kim, 1990; Takahashi et al., 1998; Marmier et al., 1999), opal is commonly believed to be an insignificant YREE scavenger in marine systems or large lakes (Murray and Leinen, 1993; Sholkovitz et al., 1994; Kuss et al., 2001; Tanaka et al., 2007; Xiong et al., 2012). This is in sharp contrast to recent claims by Akagi et al. (2011) and Akagi (2013), who founded their conclusions on analyses of opal corrected for a detrital signal that actually constitutes most of the vertical YREE flux in the diatom-dominated Bering Sea, as well as on an erroneous speciation model. There are many laboratory studies of YREE sorption on clay minerals (Aagaard, 1974; Bruque et al., 1980; Takahashi et al., 2004; Tertre et al., 2005; Wan and Liu, 2005) yet most involve just one element (Kowal-Fouchard et al., 2004; Bradbury et al., 2005; Rabung et al., 2005; Tertre et al., 2006) and, as far as we know, none were done in seawater. González López et al. (2005) reported MREE-enriched patterns (when normalized against Upper Continental Crust) for siltstones and claystones from kaolinite-rich rocks of marine origin that underwent only early diagenesis. However, these contain many potentially YREE-rich accessory minerals and being of Lower Cretaceous age it is difficult to know what seawater YREE composition or speciation should be used to calculate distribution coefficients. The authors conclude that clay minerals are not "the main phase in the REE control" of these marine sedimentary rocks. 


\subsection{Comparisons of the best-matching solid phases with marine particulate matter}

Marine geochemists have tried to shed light on YREE scavenging in seawater by directly analyzing either small suspended particles collected by filtration, or larger sinking particles collected with sediment traps. The interpretation of such data can be challenging because the residence time of particles is typically much shorter than that of the water from which the particles are obtained (Fowler et al., 1992) hence they may not present an instantaneous signal of scavenging but rather one that is integrated across the overlying water column. It is furthermore difficult to measure the size, surface area, and even the composition of natural particles. A few strategies exist to circumvent these problems. In many studies, selective leaching techniques (Sholkovitz et al., 1994; Lerche and Nozaki, 1998; Akagi et al., 2011) or some version of Principal Components Analysis (Murphy and Dymond, 1984; Kuss et al., 2001; Takebe, 2005) were used to separate various empirically defined fractions of bulk particulate matter. In others, the contribution of detrital YREEs is subtracted by employing known ratios of the YREEs and an element unique to that fraction, like $\mathrm{Al}$ or Ti (Murray and Leinen, 1993; Tachikawa et al., 1999b). Analysis of the ${ }^{143} \mathrm{Nd} /{ }^{144} \mathrm{Nd}$ isotopic ratio has been a powerful tool for quantifying rapid YREE exchange at the particle-water interface without net removal (Bertram and Elderfield, 1993; Tachikawa et al., 1997, 1999a). Arraes-Mescoff et al. (2001) investigated YREE release during the decomposition of large marine particles in laboratory incubations. Several groups have stressed the importance of manganese oxides as YREE carriers (Masuzawa and Koyama, 1989; Sholkovitz et al., 1994; Takebe, 2005), although there are dissenting views (Kuss et al., 2001). It may therefore be instructive to compare the distribution coefficient patterns for HMO and $U$. lactuca with the YREE contents of marine particles.

In Figure 6, HMO and $U$. lactuca are compared with two datasets for YREE concentrations in marine particles. Here, the distribution coefficient patterns were vertically shifted to maximize overlap with the particle patterns and the number of shared elements is smaller. Figure 6A shows the 25\% acetic acid leach, which releases YREE cations that are weakly bound or contained in the calcite and manganese oxide fractions, for particles from $200 \mathrm{~m}$ and $2000 \mathrm{~m}$ depth in the Sargasso Sea, normalized to YREE concentrations in the surrounding seawater (Sholkovitz et al., 1994). The authors showed that their patterns are very similar in shape to patterns calculated for particles from the Indian Ocean, analyzed by Bertram and Elderfield (1993). Particles were obtained by $0.4-\mu \mathrm{m}$ filtration of $28-\mathrm{L}$ samples collected with GoFlo bottles. We converted 
reported distribution coefficients, $\log \mathrm{K}_{\mathrm{D}}$, from total to free concentrations, using our YREE solution speciations at pH 7.8 for the $200-\mathrm{m}$ and at pH 7.4 for the $2000-\mathrm{m}$ sample (Fig. 2). The YREE concentrations were measured via ID-TIMS and are thus lacking the mono-isotopic elements. Figure 6B shows data for suspended particles from $100 \mathrm{~m}$ and $2500 \mathrm{~m}$ depth at a mesotrophic station in the eastern Atlantic Ocean that were collected with an in-situ 0.65- $\mu$ m filtration system and corrected for detrital YREE contributions by using the YREE/Al ratio (Tachikawa et al., 1999b). Due to an analytical artifact, ICP-MS data for Y, Eu, Tb, Ho, Tm, and

$\mathrm{Lu}$ were not reported. We converted partition coefficients to $\log \mathrm{K}_{\mathrm{D}}$ values using ancillary data provided by Tachikawa et al. (1999b) and our YREE solution speciations at pH 8.2 and 7.4 (Fig. 2) for the 100-m and 2500-m sample, respectively.

Despite the missing elements, particles from the Atlantic Ocean are in better agreement with U. lactuca in shallow seawater and with HMO in deep seawater, as expected (Section 3.4). The only exception is the shallow sample from the Sargasso Sea, which better matches the distribution coefficient pattern for HMO (Fig. 6A). It may be that the sequential leaching method of Sholkovitz et al. (1994) biased the outcome for both the shallow and deep Sargasso Sea samples. Note however that all four particle samples have a positive Ce anomaly, a feature that is unique to HMO and not acquired by any of the other solids phases (Fig. 5).

\section{Summary and implications}

No uncertainties are indicated in Figures 5 and 6 for the distribution coefficients or any of the model curves. If distribution coefficients or stability constants are measured simultaneously for all YREEs, their analytical errors are highly correlated across the lanthanide series (e.g., Quinn et al., 2006a) and have no effect on the slope or shape of the pattern. Errors that could affect the slope or shape are those associated with the A-term and the L-term (Eq. 9). The slope of the L-term appears to be foremost a function of seawater $\mathrm{pH}$ and the degree of YREE organic complexation (Fig. 3). The L-term results from an iterative calculation involving numerous ion-pairing and stability constants, and component concentrations (Section 3.1). Estimating its uncertainty by propagating the known errors of these parameters is consequently not feasible, and would in reality require a sophisticated sensitivity analysis that is beyond the scope of this work. Analytical errors in the A-term, usually on the order of 1-2\% (Shabani et al., 1992), are not a good indicator of the natural variability of seawater pattern slopes and shapes, which is 
more suitably illustrated by a selection of patterns from widespread locations and depths (Fig. 4).

Figure 7 contains minimized sum-of-squares differences for all pairwise comparisons between distribution coefficient patterns and model curves of log $\overline{\mathrm{K}}_{\mathrm{S}}$ (left panel) or particle patterns (right panel). Each bar in the graph represents a pair of patterns, one member indicated by the shading of the bar and the other by the x-axis label. Without knowing true uncertainties, it allows a quantitative evaluation of the spectrum of agreement across different locations, depths, and solid phases, whereby smaller values indicate a better match. Sum-of-squares differences should not be compared between the two panels, since the number of shared elements is not the same. The graph shows at a glance that $U$. lactuca, calcite (disregarding the pattern of Tanaka and Kawabe, 2006), and HFO are all a better match in shallow than in deep seawater, and better in the Atlantic than in the Pacific. In contrast, HMO is a better match in deep seawater and in the Pacific. The agreement for U. lactuca in shallow Atlantic seawater is better than for calcite and HFO, in that order, but it is worse than for HMO in deep Pacific seawater. The match between the $\log \bar{K}_{\mathrm{S}}$ pattern of the B\&K model and U. lactuca (i.e., organic matter) is substantially worse than the best ones generated by our inverted scavenging model. Suspended particles are in excellent agreement with $U$. lactuca in the shallow Atlantic and with HMO in the deep Atlantic, except in the Sargasso Sea where both shallow and deep particles resemble HMO, possibly due to the use of a selective leaching method (Sholkovitz et al., 1994).

Our inverted scavenging model, a modification and refinement of the model devised by Byrne and Kim (1990), subtracts high-quality shale-normalized YREE patterns for shallow and deep open ocean waters from the L-term, calculated from YREE solution speciation, to derive $\log \overline{\mathrm{K}}_{\mathrm{S}}$ (Eq. 9), which theoretically represents average relative YREE affinities for marine particles. The nature of these particles is then investigated by comparing our model curves with patterns of distribution coefficients for YREE sorption on relevant solid phases, measured in laboratory experiments at seawater conditions. Figure 7 suggests that model curves for shallow seawater, calculated at $\mathrm{pH} 8.2$ and including YREE complexation with strong organic ligands, have some features in common with distribution coefficient patterns for the green macroalga Ulva lactuca, a substitute for organic matter, and for calcite and HFO, but do not match any of them exactly. Especially good agreement is found between model curves for deep seawater and distribution coefficient patterns for HMO. Marine particles near the ocean surface are likely to be a complex assemblage of different biogenic (organic matter, calcite, opal) and authigenic (Fe-Mn 
oxides, clays) phases. It is possible that our model curves for shallow seawater would overlap more closely with a linear combination of the various distribution coefficient patterns, but we did not attempt this. Other quasi-equilibrium processes, such as the slow dissolution of atmospheric dust particles (Sholkovitz et al., 1993; Greaves et al., 1994), and non-equilibrium processes, such as active microbial uptake and photochemistry (Moffett, 1994), may play a role in YREE scavenging. In addition, marine particles themselves are subject to highly dynamic cycles of aggregation and disaggregation, so that a more sophisticated, kinetic scavenging model may well be required (Jannasch et al., 1988). Finally, scavenging in the upper ocean is dominated by ubiquitous organic and Fe-Mn oxide coatings that obscure the surface of most particles (Byrne and Kim, 1990; Sholkovitz et al., 1994). The superior match of the model curves for deep seawater with the distribution coefficient pattern for HMO (Fig. 5C) may thus indicate that particles in the abyssal ocean are more homogeneous and less subject to dynamic cycling, and that YREE scavenging is mediated by manganese oxides lacking an organic surface coating, probably because it has been stripped off by bacterial decomposition.

In conclusion, manganese oxides may be the dominant scavenger of YREEs throughout the abyssal ocean, and perhaps even in the upper water column. Near the ocean surface, where marine particulate matter comprises a complex assemblage of biogenic and authigenic phases, altered by reactive coatings and subject to many non-equilibrium mechanical and chemical processes, more sophisticated kinetic models of YREE scavenging may be needed, particularly for the redox-driven scavenging of Ce(III). The influence of complexation with strong organic ligands on YREE scavenging also merits further study.

\section{Acknowledgements}

Partial funding was provided to J.S. by NSF (OCE-0745881; OCE-0928450). Acknowledgment is made to the Donors of the American Chemical Society Petroleum Research Fund for support of this research (49028-DNI2). Kathleen Marshall is thanked for sharing her unpublished measurements of YREE sorption on hydrous manganese oxide. Our manuscript was substantially improved by comments from Karen Johannesson and one anonymous reviewer. We also owe gratitude to guest editor Loes Gerringa for her efforts to bring about this special issue. J.S. would like to dedicate this paper to Hein de Baar who, as his former co-promotor, saved him from the empty promises of experimental nuclear physics and put him firmly on the righteous path of rare earth element marine geochemistry. This is UMCES publication \#5004. 


\section{References}

Aagaard, P., 1974. Rare earth elements adsorption on clay minerals. Bull. Gr. Franç. Argil., 26: 193-199.

Akagi, T., Fu, F.-F., Hongo, Y. and Takahashi, K., 2011. Composition of rare earth elements in settling particles collected in the highly productive North Pacific Ocean and Bering Sea: Implications for siliceous-matter dissolution kinetics and formation of two REE-enriched phases. Geochim. Cosmochim. Acta, 75: 4857-4876.

Akagi, T., 2013. Rare earth element (REE)-silicic acid complexes in seawater explain the incorporation of REEs in opal and the "leftover" REEs in surface water: New interpretation of dissolved REE distribution profiles. Geochim. Cosmochim. Acta, 113: 174-192.

Alibo, D.S. and Nozaki, Y., 1999. Rare earth elements in seawater: Particle association, shalenormalization, and Ce oxidation. Geochim. Cosmochim. Acta, 63: 363-372.

Alibo, D.S. and Nozaki, Y., 2000. Dissolved rare earth elements in the South China Sea: Geochemical characterization of the water masses. J. Geophys. Res., 105: 28,771-28,783.

Arraes-Mescoff, R., Roy-Barman, M., Coppola, L., Souhaut, M., Tachikawa, K., Jeandel, C., Sempéré, R. and Yoro, C., 2001. The behavior of Al, Mn, Ba, Sr, REE and Th isotopes during in vitro degradation of large marine particles. Mar. Chem., 73: 1-19.

Baars, O., Abouchami, W., Galer, S.J.G., Boye, M. and Croot, P.L., 2014. Dissolved cadmium in the Southern Ocean: Distribution, speciation, and relation to phosphate. Limnol. Oceanogr., 59: 385-399.

Bertram, C.J. and Elderfield, H., 1993. The geochemical balance of the rare earth elements and neodymium isotopes in the oceans. Geochim. Cosmochim. Acta, 57: 1957-1986.

Biller, D.V. and Bruland, K.W., 2012. Analysis of Mn, Fe, Co, Ni, Cu, Zn, Cd, and Pb in seawater using the Nobias-chelate PA1 resin and magnetic sector inductively coupled plasma mass spectrometry (ICP-MS). Mar. Chem., 130-131: 12-20.

Bradbury, M.H., Baeyens, B., Geckeis, H. and Rabung, T., 2005. Sorption of Eu(III)/Cm(III) on Ca-montmorillonite and Na-illite. Part 2: Surface complexation modelling. Geochim. Cosmochim. Acta, 69: 5403-5412.

Bruland, K.W., Knauer, G.A. and Martin, J.H., 1978. Zinc in north-east Pacific water. Nature, 271: 741-743.

Bruland, K.W., 1983. Trace elements in sea-water. In: J.P. Riley and R. Chester (Eds.), Chemical Oceanography, Vol. 8. Academic Press, London, UK, pp. 157-220.

Bruque, S., Mozas, T. and Rodriguez, A., 1980. Factors influencing retention of lanthanide ions by montmorillonite. Clay Minerals, 15: 413-420.

Butler, A., 1998. Acquisition and utilization of transition metal ions by marine organisms. Science, 281: 207-209.

Butler, A. and Theisen, R.M., 2010. Iron(III)-siderophore coordination chemistry: Reactivity of marine siderophores. Coord. Chem. Rev., 254: 288-296.

Byrne, R.H. and Kester, D.R., 1974. Inorganic speciation of boron in seawater. J. Mar. Res., 32: 119-127.

Byrne, R.H., Kump, L.R. and Cantrell, K.J., 1988. The influence of temperature and pH on trace metal speciation in seawater. Mar. Chem., 25: 163-181.

Byrne, R.H. and Kim, K.-H., 1990. Rare earth element scavenging in seawater. Geochim. Cosmochim. Acta, 54: 2645-2656. 
Byrne, R.H. and Li, B., 1995. Comparative complexation behavior of the rare earths. Geochim. Cosmochim. Acta, 59: 4575-4589.

Byrne, R.H. and Sholkovitz, E.R., 1996. Marine chemistry and geochemistry of the lanthanides. In: K.A. Gschneidner Jr. and L. Eyring (Eds.), Handbook on the Physics and Chemistry of Rare Earths. Elsevier, Amsterdam, pp. 497-593.

Byrne, R.H., 2002. Speciation in seawater. In: A.M. Ure and C.M. Davidson (Eds.), Chemical Speciation in the Environment. Blackwell Science, Oxford, UK, pp. 322-357.

Capodaglio, G., Coale, K.H. and Bruland, K.W., 1990. Lead speciation in surface waters of the eastern North Pacific. Mar. Chem., 29: 221-233.

Christenson, E.A. and Schijf, J., 2011. Stability of YREE complexes with the trihydroxamate siderophore desferrioxamine B at seawater ionic strength. Geochim. Cosmochim. Acta, 75: 7047-7062.

Davranche, M., Pourret, O., Gruau, G. and Dia, A., 2004. Impact of humate complexation on the adsorption of REE onto Fe oxyhydroxide. J. Colloid Interf. Sci., 277: 271-279.

Davranche, M., Pourret, O., Gruau, G., Dia, A. and Le Coz-Bouhnik, M., 2005. Adsorption of $\mathrm{REE}(\mathrm{III})$-humate complexes onto $\mathrm{MnO}_{2}$ : Experimental evidence for cerium anomaly and lanthanide tetrad effect suppression. Geochim. Cosmochim. Acta, 69: 4825-4835.

Davranche, M., Pourret, O., Gruau, G., Dia, A., Jin, D. and Gaertner, D., 2008. Competitive binding of REE to humic acid and manganese oxide: Impact of reaction kinetics on development of cerium anomaly and REE adsorption. Chem. Geol., 247: 154-170.

de Baar, H.J.W., Bacon, M.P., Brewer, P.G. and Bruland, K.W., 1985. Rare earth elements in the Pacific and Atlantic Oceans. Geochim. Cosmochim. Acta, 49: 1943-1959.

de Baar, H.J.W., Saager, P.M., Nolting, R.F. and van der Meer, J., 1994. Cadmium versus phosphate in the world ocean. Mar. Chem., 46: 261-281.

Elderfield, H., 1988. The oceanic chemistry of the rare-earth elements. Phil. Trans. Royal Soc. London A, 325: 105-126.

Feely, R.A., Sabine, C.L., Lee, K., Berelson, W., Kleypas, J., Fabry, V.J. and Millero, F.J., 2004. Impact of anthropogenic $\mathrm{CO}_{2}$ on the $\mathrm{CaCO}_{3}$ system in the oceans. Science, 305: 362-366.

Fowler, S.W., Hamilton, T.F., Peinert, R.D., La Rosa, J. and Teyssie, J.-L., 1992. The vertical flux of rare earth elements in the northwestern Mediterranean. In: J.-M. Martin and H. Barth (Eds.), EROS 2000 (European River Ocean System), Third Workshop on the North-West Mediterranean Sea, Den Burg, The Netherlands, October 21-25, 1991. Water Pollution Research Report Vol. 28. Commission of the European Communities, pp. 401-412.

Garcia-Solsona, E., Jeandel, C., Labatut, M., Lacan, F., Vance, D., Chavagnac, V. and Pradoux, C., 2014. Rare earth elements and Nd isotopes tracing water mass mixing and particleseawater interactions in the SE Atlantic. Geochim. Cosmochim. Acta, 125: 351-372.

Gonzalez-Davila, M., Santana-Casiano, J.M., Perez-Peña, J. and Millero, F.J., 1995. Binding of $\mathrm{Cu}(\mathrm{II})$ to the surface and exudates of the alga Dunaliella tertiolecta in seawater. Environ. Sci. Technol., 29: 289-301.

González López, J.M., Bauluz, B., Fernández-Nieto, C. and Oliete, A.Y., 2005. Factors controlling the trace-element distribution in fine-grained rocks: the Albian kaolinite-rich deposits of the Oliete Basin (NE Spain). Chem. Geol., 214: 1-19.

Greaves, M.J., Elderfield, H. and Klinkhammer, G.P., 1989. Determination of the rare earth elements in natural waters by isotope-dilution mass spectrometry. Anal. Chim. Acta, 218: 265-280. 
Greaves, M.J., Statham, P.J. and Elderfield, H., 1994. Rare earth element mobilization from marine atmospheric dust into seawater. Mar. Chem., 46: 255-260.

Haley, B.A., Klinkhammer, G.P. and Mix, A.C., 2005. Revisiting the rare earth elements in foraminiferal tests. Earth Planet. Sci. Lett., 239: 79-97.

Haley, B.A., Frank, M., Hathorne, E. and Pisias, N., 2014. Biogeochemical implications from dissolved rare earth element and $\mathrm{Nd}$ isotope distributions in the Gulf of Alaska. Geochim. Cosmochim. Acta, 126: 455-474.

Hathorne, E.C., Stichel, T., Brück, B. and Frank, M., 2015. Rare earth element distribution in the Atlantic sector of the Southern Ocean: The balance between particle scavenging and vertical supply. Mar. Chem.: http://dx.doi.org/10.1016/j.marchem.2015.03.011.

Hongo, Y., Obata, H., Alibo, D.S. and Nozaki, Y., 2006. Spatial variations of rare earth elements in North Pacific surface water. J. Oceanogr., 62: 441-455.

Jakuba, R.W., Saito, M.A., Moffett, J.W. and Xu, Y., 2012. Dissolved zinc in the subarctic North Pacific and Bering Sea: Its distribution, speciation, and importance to primary producers. Glob. Biogeochem. Cycl., 26: GB2015, doi:10.1029/2010GB004004.

Jannasch, H.W., Honeyman, B.D., Balistrieri, L.S. and Murray, J.W., 1988. Kinetics of trace element uptake by marine particles. Geochim. Cosmochim. Acta, 52: 567-577.

Klungness, G.D. and Byrne, R.H., 2000. Comparative hydrolysis behavior of the rare earths and yttrium: the influence of temperature and ionic strength. Polyhedron, 19: 99-107.

Kowal-Fouchard, A., Drot, R., Simoni, E., Marmier, N., Fromage, F. and Ehrhardt, J.-J., 2004. Structural identification of europium(III) adsorption complexes on montmorillonite. New J. Chem., 28: 864-869.

Kuss, J., Garbe-Schönberg, C.-D. and Kremling, K., 2001. Rare earth elements in suspended particulate material of North Atlantic surface waters. Geochim. Cosmochim. Acta, 65: 187199.

Lee, J.G., Roberts, S.B. and Morel, F.M.M., 1995. Cadmium: A nutrient for the marine diatom Thalassiosira weissflogii. Limnol. Oceanogr., 40: 1056-1063.

Lerche, D. and Nozaki, Y., 1998. Rare earth elements of sinking particulate matter in the Japan Trench. Earth Planet. Sci. Lett., 159: 71-86.

Loder, T.C. and Liss, P.S., 1985. Control by organic coatings of the surface charge of estuarine suspended particles. Limnol. Oceanogr., 30: 418-421.

Luo, Y.-R. and Byrne, R.H., 2001. Yttrium and rare earth element complexation by chloride ions at $25^{\circ} \mathrm{C}$. J. Solut. Chem., 30: 837-845.

Luo, Y.-R. and Byrne, R.H., 2004. Carbonate complexation of yttrium and the rare earth elements in natural waters. Geochim. Cosmochim. Acta, 68: 691-699.

Marmier, N., Delisée, A. and Fromage, F., 1999. Surface complexation modeling of Yb(III) and Cs(I) sorption on silica. J. Colloid Interf. Sci., 212: 228-233.

Martell, A.E. and Smith, R.M., 1977. Critical Stability Constants, Vol. 3: Other Organic Ligands. Plenum Press, New York, 643 pp.

Martell, A.E. and Smith, R.M., 1982. Critical Stability Constants, Vol. 5: First Supplement. Plenum Press, New York, 622 pp.

Martell, A.E., Smith, R.M. and Motekaitis, R.J., 2004. NIST Critically Selected Stability Constants of Metal Complexes. NIST Standard Reference Database 46 Version 8.0, Texas A\&M University. 
Martínez-Botí, M.A., Vance, D. and Mortyn, P.G., 2009. Nd/Ca ratios in plankton-towed and core top foraminifera: Confirmation of the water column acquisition of $\mathrm{Nd}$. Geochem. Geophys. Geosyst., 10: Q08018, doi:10.1029/2009GC002701.

Masuzawa, T. and Koyama, M., 1989. Settling particles with positive Ce anomalies from the Japan Sea. Geophys. Res. Lett., 16: 503-506.

Mawji, E., Gledhill, M., Milton, J.A., Tarran, G.A., Ussher, S., Thompson, A., Wolff, G.A., Worsfold, P.J. and Achterberg, E.P., 2008. Hydroxamate siderophores: Occurrence and importance in the Atlantic Ocean. Environ. Sci. Technol., 42: 8675-8680.

McLennan, S.M., 1989. Rare earth elements in sedimentary rocks: Influence of provenance and sedimentary processes. In: B.R. Lipin and G.A. McKay (Eds.), Geochemistry and Mineralogy of Rare Earth Elements. Mineralogical Society of America, Washington, DC, pp. 169-200.

Millero, F.J. and Schreiber, D.R., 1982. Use of the ion pairing model to estimate activity coefficients of the ionic components of natural waters. Am. J. Sci., 282: 1508-1540.

Moffett, J.W., 1994. A radiotracer study of cerium and manganese uptake onto suspended particles in Chesapeake Bay. Geochim. Cosmochim. Acta, 58: 695-703.

Molina-Kescher, M., Frank, M. and Hathorne, E., 2014. South Pacific dissolved Nd isotope compositions and rare earth element distributions: Water mass mixing versus biogeochemical cycling. Geochim. Cosmochim. Acta, 127: 171-189.

Monecke, T., Kempe, U., Monecke, J., Sala, M. and Wolf, D., 2002. Tetrad effect in rare earth element distribution patterns: A method of quantification with application to rock and mineral samples from granite-related rare metal deposits. Geochim. Cosmochim. Acta, 66: 1185-1196.

Murphy, K. and Dymond, J., 1984. Rare earth element fluxes and geochemical budget in the eastern equatorial Pacific. Nature, 307: 444-447.

Murray, R.W. and Leinen, M., 1993. Chemical transport to the seafloor of the equatorial Pacific Ocean across a latitudinal transect at $135^{\circ} \mathrm{W}$ : Tracking sedimentary major, trace, and rare earth element fluxes at the Equator and the Intertropical Convergence Zone. Geochim. Cosmochim. Acta, 57: 4141-4163.

Ngwenya, B.T., Mosselmans, J.F.W., Magennis, M., Atkinson, K.D., Tourney, J., Olive, V. and Ellam, R.M., 2009. Macroscopic and spectroscopic analysis of lanthanide adsorption to bacterial cells. Geochim. Cosmochim. Acta, 73: 3134-3147.

Nozaki, Y., Zhang, J. and Amakawa, H., 1997. The fractionation between Y and Ho in the marine environment. Earth Planet. Sci. Lett., 148: 329-340.

Nozaki, Y., Alibo, D.-S., Amakawa, H., Gamo, T. and Hasumoto, H., 1999. Dissolved rare earth elements and hydrography in the Sulu Sea. Geochim. Cosmochim. Acta, 63: 2171-2181.

Nozaki, Y. and Alibo, D.S., 2003a. Dissolved rare earth elements in the Southern Ocean, southwest of Australia: Unique patterns compared to the South Atlantic data. Geochem. J., 37: 47-62.

Nozaki, Y. and Alibo, D.S., 2003b. Importance of vertical geochemical processes in controlling the oceanic profiles of dissolved rare earth elements in the northeastern Indian Ocean. Earth Planet. Sci. Lett., 205: 155-172.

Nuester, J., Vogt, S. and Twining, B.S., 2012. Localization of iron within centric diatoms of the genus Thalassiosira. J. Phycol., 48: 626-634.

Ohta, A. and Kawabe, I., 2001. REE(III) adsorption onto $\mathrm{Mn}$ dioxide $\left(\delta-\mathrm{MnO}_{2}\right)$ and Fe oxyhydroxide: $\mathrm{Ce}(\mathrm{III})$ oxidation by $\delta-\mathrm{MnO}_{2}$. Geochim. Cosmochim. Acta, 65: 695-703. 
Osborne, A.H., Haley, B.A., Hathorne, E.C., Flögel, S. and Frank, M., 2014. Neodymium isotopes and concentrations in Caribbean seawater: Tracing water mass mixing and continental input in a semi-enclosed ocean basin. Earth Planet. Sci. Lett., 406: 174-186.

Osborne, A.H., Haley, B.A., Hathorne, E.C., Plancherel, Y. and Frank, M., 2015. Rare earth element distribution in Caribbean seawater: Continental inputs versus lateral transport of distinct REE compositions in subsurface water masses. Mar. Chem.: http://dx.doi.org/10.1016/j.marchem.2015.03.013.

Pahnke, K., van de Flierdt, T., Jones, K.M., Lambelet, M., Hemming, S.R. and Goldstein, S.L., 2012. GEOTRACES intercalibration of neodymium isotopes and rare earth element concentrations in seawater and suspended particles. Part 2: Systematic tests and baseline profiles. Limnol. Oceanogr. Meth., 10: 252-269.

Piepgras, D.J. and Jacobsen, S.B., 1992. The behavior of rare earth elements in seawater: Precise determination of variations in the North Pacific water column. Geochim. Cosmochim. Acta, 56: 1851-1862.

Pižeta, I., Sander, S.G., Hudson, R.J.M., Omanović, D., Baars, O., Barbeau, K.A., Buck, K.N., Bundy, R.M., Carrasco, G., Croot, P.L., Garnier, C., Gerringa, L.J.A., Gledhill, M., Hirose, K., Kondo, Y., Laglera, L.M., Nuester, J., Rijkenberg, M.J.A., Takeda, S., Twining, B.S. and Wells, M., 2015. Interpretation of complexometric titration data: An intercomparison of methods for estimating models of trace metal complexation by natural organic ligands. Mar. Chem., 173: 3-24.

Pol, A., Barends, T.R.M., Dietl, A., Khadem, A.F., Eygensteyn, J., Jetten, M.S.M. and Op den Camp, H.J.M., 2014. Rare earth metals are essential for methanotrophic life in volcanic mudpots. Environ. Microbiol., 16: 255-264.

Pourret, O., Davranche, M., Gruau, G. and Dia, A., 2007. Competition between humic acid and carbonates for rare earth elements complexation. J. Colloid Interf. Sci., 305: 25-31.

Pourret, O. and Martinez, R.E., 2009. Modeling lanthanide series binding sites on humic acid. J. Colloid Interf. Sci., 330: 45-50.

Quinn, K.A., Byrne, R.H. and Schijf, J., 2006a. Sorption of yttrium and rare earth elements by amorphous ferric hydroxide: Influence of $\mathrm{pH}$ and ionic strength. Mar. Chem., 99: 128-150.

Quinn, K.A., Byrne, R.H. and Schijf, J., 2006b. Sorption of yttrium and rare earth elements by amorphous ferric hydroxide: Influence of solution complexation with carbonate. Geochim. Cosmochim. Acta, 70: 4151-4165.

Rabung, T., Pierret, M.C., Bauer, A., Geckeis, H., Bradbury, M.H. and Baeyens, B., 2005. Sorption on $\mathrm{Eu}(\mathrm{III}) / \mathrm{Cm}(\mathrm{III})$ on Ca-montmorillonite and Na-illite. Part 1: Batch sorption and time-resolved laser fluorescence spectroscopy experiments. Geochim. Cosmochim. Acta, 69: 5393-5402.

Roberts, N.L., Piotrowski, A.M., Elderfield, H., Eglinton, T.I. and Lomas, M.W., 2012. Rare earth element association with foraminifera. Geochim. Cosmochim. Acta, 94: 57-71.

Schijf, J. and Byrne, R.H., 2004. Determination of $\mathrm{so}_{4} \beta_{1}$ for yttrium and the rare earth elements at $I=0.66 \mathrm{~m}$ and $t=25^{\circ} \mathrm{C}$-Implications for YREE solution speciation in sulfate-rich waters. Geochim. Cosmochim. Acta, 68: 2825-2837.

Schijf, J. and Marshall, K.S., 2011. YREE sorption on hydrous ferric oxide in $0.5 \mathrm{M} \mathrm{NaCl}$ solutions: A model extension. Mar. Chem., 123: 32-43.

Schijf, J., Christenson, E.A. and Potter, K.J., 2015. Different binding modes of Cu and Pb vs. Cd, $\mathrm{Ni}$, and $\mathrm{Zn}$ with the trihydroxamate siderophore desferrioxamine $\mathrm{B}$ at seawater ionic strength. Mar. Chem., 173: 40-51. 
Schindler, P.W., 1975. Removal of trace metals from the oceans: a zero order model. Thal. Jugosl., 11: 101-111.

Shabani, M.B., Akagi, T. and Masuda, A., 1992. Preconcentration of trace rare-earth elements in seawater by complexation with bis(2-ethylhexyl) hydrogen phosphate and 2-ethylhexyl dihydrogen phosphate adsorbed on a $\mathrm{C}_{18}$ cartridge and determination by inductively coupled plasma mass spectrometry. Anal. Chem., 64: 737-743.

Sholkovitz, E.R., Church, T.M. and Arimoto, R., 1993. Rare earth element composition of precipitation, precipitation particles, and aerosols. J. Geophys. Res., 98: 20,587-20,599.

Sholkovitz, E.R., Landing, W.M. and Lewis, B.L., 1994. Ocean particle chemistry: The fractionation of rare earth elements between suspended particles and seawater. Geochim. Cosmochim. Acta, 58: 1567-1579.

Smith, R.M. and Martell, A.E., 1989. Critical Stability Constants, Vol. 6: Second Supplement. Plenum Press, New York, $662 \mathrm{pp}$.

Sonke, J.E., 2006. Lanthanide-humic substances complexation. II. Calibration of Humic IonBinding Model V. Environ. Sci. Technol., 40: 7481-7487.

Stanley, J.K., Jr. and Byrne, R.H., 1990. The influence of solution chemistry on REE uptake by Ulva lactuca L. in seawater. Geochim. Cosmochim. Acta, 54: 1587-1595.

Tachikawa, K., Jeandel, C. and Dupré, B., 1997. Distribution of rare earth elements and neodymium isotopes in settling particulate material of the tropical Atlantic Ocean (EUMELI site). Deep-Sea Res. I, 44: 1769-1792.

Tachikawa, K., Jeandel, C., Vangriesheim, A. and Dupré, B., 1999a. Distribution of rare earth elements and neodymium isotopes in suspended particles of the tropical Atlantic Ocean (EUMELI site). Deep-Sea Res. I, 46: 733-755.

Tachikawa, K., Jeandel, C. and Roy-Barman, M., 1999b. A new approach to the Nd residence time in the ocean: the role of atmospheric inputs. Earth Planet. Sci. Lett., 170: 433-446.

Takahashi, Y., Kimura, T., Kato, Y., Minai, Y. and Tominaga, T., 1998. Characterization of Eu(III) species sorbed on silica and montmorillonite by laser-induced fluorescence spectroscopy. Radiochim. Acta, 82: 227-232.

Takahashi, Y., Tada, A. and Shimizu, H., 2004. Distribution pattern of rare earth ions between water and montmorillonite and its relation to the sorbed species of the ions. Anal. Sci., 20: 1301-1306.

Takebe, M., 2005. Carriers of rare earth elements in Pacific deep-sea sediments. J. Geol., 113: 201-215.

Tanaka, K., Ohta, A. and Kawabe, I., 2004. Experimental REE partitioning between calcite and aqueous solution at $25^{\circ} \mathrm{C}$ and $1 \mathrm{~atm}$ : Constraints on the incorporation of seawater REE into seamount-type limestones. Geochem. J., 38: 19-32.

Tanaka, K. and Kawabe, I., 2006. REE abundances in ancient seawater inferred from marine limestone and experimental REE partition coefficients between calcite and aqueous solution. Geochem. J., 40: 425-435.

Tanaka, K., Akagawa, F., Yamamoto, K., Tani, Y., Kawabe, I. and Kawai, T., 2007. Rare earth element geochemistry of Lake Baikal sediment: its implication for geochemical response to climate change during the Last Glacial/Interglacial transition. Quat. Sci. Rev,, 26: 13621368.

Terakado, Y. and Masuda, A., 1988. The coprecipitation of rare-earth elements with calcite and aragonite. Chem. Geol., 69: 103-110. 
Tertre, E., Berger, G., Castet, S., Loubet, M. and Giffaut, E., 2005. Experimental sorption of $\mathrm{Ni}^{2+}, \mathrm{Cs}^{+}$and $\mathrm{Ln}^{3+}$ onto a montmorillonite up to $150^{\circ} \mathrm{C}$. Geochim. Cosmochim. Acta, 69: 4937-4948.

Tertre, E., Berger, G., Simoni, E., Castet, S., Giffaut, E., Loubet, M. and Catalette, H., 2006. Europium retention onto clay minerals from 25 to $150{ }^{\circ} \mathrm{C}$ : Experimental measurements, spectroscopic features and sorption modelling. Geochim. Cosmochim. Acta, 70: 4563-4578.

Toyama, K. and Terakado, Y., 2014. Experimental study of rare earth element partitioning between calcite and sodium chloride solutions at room temperature and pressure. Geochem. J., 48: 463-477.

Trick, C.G., 1989. Hydroxamate-siderophore production and utilization by marine eubacteria. Curr. Microbiol., 18: 375-378.

Turner, D.R., Whitfield, M. and Dickson, A.G., 1981. The equilibrium speciation of dissolved components in freshwater and seawater at $25^{\circ} \mathrm{C}$ and $1 \mathrm{~atm}$ pressure. Geochim. Cosmochim. Acta, 45: 855-881.

van de Flierdt, T., Pahnke, K., Amakawa, H., Andersson, P., Basak, C., Coles, B., Colin, C., Crocket, K., Frank, M., Frank, N., Goldstein, S.L., Goswami, V., Haley, B.A., Hathorne, E.C., Hemming, S.R., Henderson, G.M., Jeandel, C., Jones, K., Kreissig, K., Lacan, F., Lambelet, M., Martin, E.E., Newkirk, D.R., Obata, H., Pena, L., Piotrowski, A.M., Pradoux, C., Scher, H.D., Schöberg, H., Singh, S.K., Stichel, T., Tazoe, H., Vance, D. and Yang, J., 2012. GEOTRACES intercalibration of neodymium isotopes and rare earth element concentrations in seawater and suspended particles. Part 1: reproducibility of results for the international intercomparison. Limnol. Oceanogr. Meth., 10: 234-251.

Vraspir, J.M. and Butler, A., 2009. Chemistry of marine ligands and siderophores. Ann. Rev. Mar. Sci., 1: 43-63.

Wan, Y. and Liu, C., 2005. Study on adsorption of rare earth elements by kaolinite. J. Rare Earths, 23: 377-381.

Westall, J.C., Zachary, J.L. and Morel, F.M.M., 1986. MINEQL. A Computer Program for the Calculation of the Chemical Equilibrium Composition of Aqueous Systems. Version 1. Report 86-01, Department of Chemistry, Oregon State University, Corvallis, OR.

Wuttig, K., Heller, M.I. and Croot, P.L., 2013. Reactivity of inorganic $\mathrm{Mn}$ and $\mathrm{Mn}$ desferrioxamine B with $\mathrm{O}_{2}, \mathrm{O}_{2}{ }^{-}$, and $\mathrm{H}_{2} \mathrm{O}_{2}$ in seawater. Environ. Sci. Technol., 47: 10,257$10,265$.

Xiong, Z., Li, T., Algeo, T., Chang, F., Yin, X. and Xu, Z., 2012. Rare earth element geochemistry of laminated diatom mats from tropical West Pacific: Evidence for more reducing bottomwaters and higher primary productivity during the Last Glacial Maximum. Chem. Geol., 296-297: 103-118.

Zhang, J. and Nozaki, Y., 1996. Rare earth elements and yttrium in seawater: ICP-MS determinations in the East Caroline, Coral Sea, and South Fiji basins of the western South Pacific Ocean. Geochim. Cosmochim. Acta, 60: 4631-4644.

Zhong, S. and Mucci, A., 1995. Partitioning of rare earth elements (REEs) between calcite and seawater solutions at $25^{\circ} \mathrm{C}$ and $1 \mathrm{~atm}$, and high dissolved REE concentrations. Geochim. Cosmochim. Acta, 59: 443-453.

Zoll, A.M. and Schijf, J., 2012. A surface complexation model of YREE sorption on Ulva lactuca in 0.05-5.0 M NaCl solutions. Geochim. Cosmochim. Acta, 97: 183-199. 
Table 1. Ion-pairing constants, $K_{M X}^{*}$, for major cations and anions in seawater $(I=0.7)$ taken from Millero and Schreiber (1982). Protonation constants for (bi)carbonate (Luo and Byrne, 2004), measured in $0.7 \mathrm{~m} \mathrm{NaClO}_{4}$, were converted to the free-ion concentration scale using ion-pairing constants for $\mathrm{Na}^{+}$and $\mathrm{pK}_{0}=1.52$. The ionization constant of water $\left(0.7 \mathrm{M} \mathrm{NaClO}_{4}\right)$ is from Christenson and Schijf (2011). Constants for borate are from Byrne and Kester (1974).

\begin{tabular}{|c|c|c|c|c|c|c|}
\hline & \multicolumn{5}{|c|}{ M } \\
\hline & & $\mathrm{H}^{+}$ & $\mathrm{Na}^{+}$ & $\mathrm{K}^{+}$ & $\mathrm{Mg}^{2+}$ & $\mathrm{Ca}^{2+}$ \\
\hline \multirow{6}{*}{$X$} & $\mathrm{Cl}^{-}$ & - & - & - & - & - \\
\hline & $\mathrm{SO}_{4}^{2-}$ & 30.9 & 2.0 & 1.8 & 10.2 & 10.8 \\
\hline & $\mathrm{HCO}_{3}^{-}$ & $10^{6.13}$ & 0.30 & - & 1.9 & 2.1 \\
\hline & $\mathrm{CO}_{3}^{2-}$ & $10^{9.92}$ & 2.6 & - & 87 & 126 \\
\hline & $\mathrm{OH}^{-}$ & $10^{13.74}$ & - & - & 50 & - \\
\hline & $\mathrm{B}(\mathrm{OH})_{4}^{-}$ & $10^{9.00}$ & 0.57 & - & 8.03 & 13.0 \\
\hline
\end{tabular}


Table 2. Stability constants ( $\mathrm{I}=0.7$ ) for YREE complexes with the major seawater anions and with desferrioxamine B (DFOB), which is taken to represent a strong organic ligand. Data for (bi)carbonate are from Luo and Byrne (2004), for chloride from Luo and Byrne (2001), for sulfate from Schijf and Byrne (2004), for hydroxide ( $\log \beta_{1}^{*}$ ) from Klungness and Byrne (2000), and for DFOB from Christenson and Schijf (2011). Values for DFOB are from direct measurements; all others were calculated from extended Debije-Hückel relations given in the corresponding papers. Values for (bi)carbonate, measured in $0.7 \mathrm{~m} \mathrm{NaClO}_{4}$, were converted to the free-ion concentration scale using ion-pairing constants for $\mathrm{Na}^{+}$(Table 1). Stability constants for the Ce-DFOB complexes could not be determined due to rapid oxidation of Ce(III) by the ligand (see Christenson and Schijf, 2011).

\begin{tabular}{|l|ccc|c|c|c|ccc|}
\hline $\mathrm{M}$ & $\log _{\mathrm{CO}_{3}} \beta_{1}$ & $\log _{\mathrm{CO}_{3}} \beta_{2}$ & $\log _{\mathrm{HCO}_{3}} \beta_{1}$ & $\log _{\mathrm{Cl}} \beta_{1}$ & $\log _{\mathrm{SO}_{4}} \beta_{1}$ & $\log \beta_{1}^{*}$ & $\log _{\mathrm{DFOB}} \beta_{1}$ & $\log _{\mathrm{DFOB}} \beta_{2}$ & $\log _{\mathrm{DFOB}} \beta_{3}$ \\
\hline $\mathrm{Y}$ & 6.18 & 10.99 & 1.37 & -0.40 & 1.82 & -8.11 & 6.16 & 10.51 & 13.98 \\
$\mathrm{La}$ & 5.43 & 9.66 & 1.39 & -0.40 & 1.93 & -9.12 & 4.88 & 7.70 & 10.09 \\
$\mathrm{Ce}$ & 5.76 & 10.12 & 1.36 & -0.40 & 1.93 & -8.65 & - & - & - \\
$\mathrm{Pr}$ & 5.93 & 10.44 & 1.30 & -0.40 & 1.94 & -8.63 & 5.45 & 8.96 & 11.96 \\
$\mathrm{Pm}$ & 5.98 & 10.53 & 1.33 & -0.40 & 1.92 & -8.49 & 5.54 & 9.24 & 12.33 \\
$\mathrm{Sm}$ & 6.16 & 10.89 & 1.39 & -0.40 & 1.95 & -8.15 & 5.93 & 10.09 & 13.38 \\
$\mathrm{Eu}$ & 6.18 & 10.99 & 1.52 & -0.40 & 1.96 & -8.07 & 6.07 & 10.32 & 13.67 \\
$\mathrm{Gd}$ & 6.09 & 10.84 & 1.41 & -0.40 & 1.93 & -8.14 & 6.04 & 10.31 & 13.67 \\
$\mathrm{~Tb}$ & 6.16 & 11.14 & 1.51 & -0.40 & 1.91 & -7.95 & 6.24 & 10.67 & 14.15 \\
$\mathrm{Dy}$ & 6.26 & 11.27 & 1.55 & -0.40 & 1.89 & -7.90 & 6.35 & 10.83 & 14.40 \\
$\mathrm{Ho}$ & 6.25 & 11.36 & 1.51 & -0.40 & 1.86 & -7.87 & 6.32 & 10.89 & 14.53 \\
$\mathrm{Er}$ & 6.31 & 11.48 & 1.54 & -0.40 & 1.83 & -7.83 & 6.38 & 10.99 & 14.66 \\
$\mathrm{Tm}$ & 6.38 & 11.63 & 1.57 & -0.40 & 1.80 & -7.70 & 6.44 & 11.13 & 14.90 \\
$\mathrm{Yb}$ & 6.51 & 11.66 & 1.58 & -0.40 & 1.78 & -7.55 & 6.53 & 11.27 & 15.17 \\
$\mathrm{Lu}$ & 6.45 & 11.73 & 1.54 & -0.40 & 1.76 & -7.58 & 6.48 & 11.25 & 15.19 \\
\hline
\end{tabular}


Table 3. Inorganic speciation of the YREEs in seawater at $\mathrm{S}=35$ and $\mathrm{pH}=8.2$ (total scale), calculated with MINEQL2.0 using the ion-pairing and stability constants in Tables 1 and 2. Fluoride complexation of the YREEs is negligible and was omitted. Species contributions are expressed as a percentage of the total dissolved YREE concentration, rounded to one decimal place. Due to rounding, which does not reflect statistical uncertainties, the contributions of all species may not add to exactly $100 \%$. The last column contains the first term on the right-hand side of Eq. 9 (the L-term).

\begin{tabular}{|l|ccccccc|c|}
\hline $\mathrm{M}$ & $\mathrm{MCO}_{3}^{+}$ & $\mathrm{M}\left(\mathrm{CO}_{3}\right)_{2}^{-}$ & $\mathrm{M}^{3+}$ & $\mathrm{MCl}^{2+}$ & $\mathrm{MSO}_{4}^{+}$ & $\mathrm{MOH}^{2+}$ & $\mathrm{MHCO}_{3}^{2+}$ & $\log \mathrm{M}_{\mathrm{T}} /[\mathrm{M}]$ \\
\hline $\mathrm{Y}$ & 27.0 & 71.4 & 0.4 & 0.1 & 0.3 & 0.7 & $<0.05$ & 2.36 \\
$\mathrm{La}$ & 52.3 & 36.4 & 4.8 & 1.0 & 4.5 & 0.8 & 0.2 & 1.32 \\
$\mathrm{Ce}$ & 48.7 & 45.7 & 2.1 & 0.5 & 2.0 & 1.0 & 0.1 & 1.68 \\
$\mathrm{Pr}$ & 41.6 & 55.1 & 1.2 & 0.3 & 1.2 & 0.6 & $<0.05$ & 1.92 \\
$\mathrm{Nd}$ & 39.6 & 57.5 & 1.0 & 0.2 & 0.9 & 0.7 & $<0.05$ & 1.99 \\
$\mathrm{Pm}$ & - & - & - & - & - & - & - & - \\
$\mathrm{Sm}$ & 30.7 & 67.4 & 0.5 & 0.1 & 0.5 & 0.8 & $<0.05$ & 2.28 \\
$\mathrm{Eu}$ & 27.0 & 71.2 & 0.4 & 0.1 & 0.4 & 0.8 & $<0.05$ & 2.36 \\
$\mathrm{Gd}$ & 29.6 & 68.2 & 0.6 & 0.1 & 0.6 & 0.9 & $<0.05$ & 2.23 \\
$\mathrm{~Tb}$ & 20.1 & 78.4 & 0.3 & 0.1 & 0.3 & 0.8 & $<0.05$ & 2.47 \\
$\mathrm{Dy}$ & 19.0 & 79.7 & 0.3 & 0.1 & 0.2 & 0.7 & $<0.05$ & 2.59 \\
$\mathrm{Ho}$ & 15.8 & 83.2 & 0.2 & $<0.05$ & 0.2 & 0.6 & $<0.05$ & 2.66 \\
$\mathrm{Er}$ & 14.1 & 85.1 & 0.2 & $<0.05$ & 0.1 & 0.5 & $<0.05$ & 2.77 \\
$\mathrm{Tm}$ & 12.0 & 87.2 & 0.1 & $<0.05$ & 0.1 & 0.5 & $<0.05$ & 2.91 \\
$\mathrm{Yb}$ & 14.6 & 84.5 & 0.1 & $<0.05$ & 0.1 & 0.7 & $<0.05$ & 2.96 \\
$\mathrm{Lu}$ & 11.3 & 88.0 & 0.1 & $<0.05$ & 0.1 & 0.6 & $<0.05$ & 3.01 \\
\hline
\end{tabular}




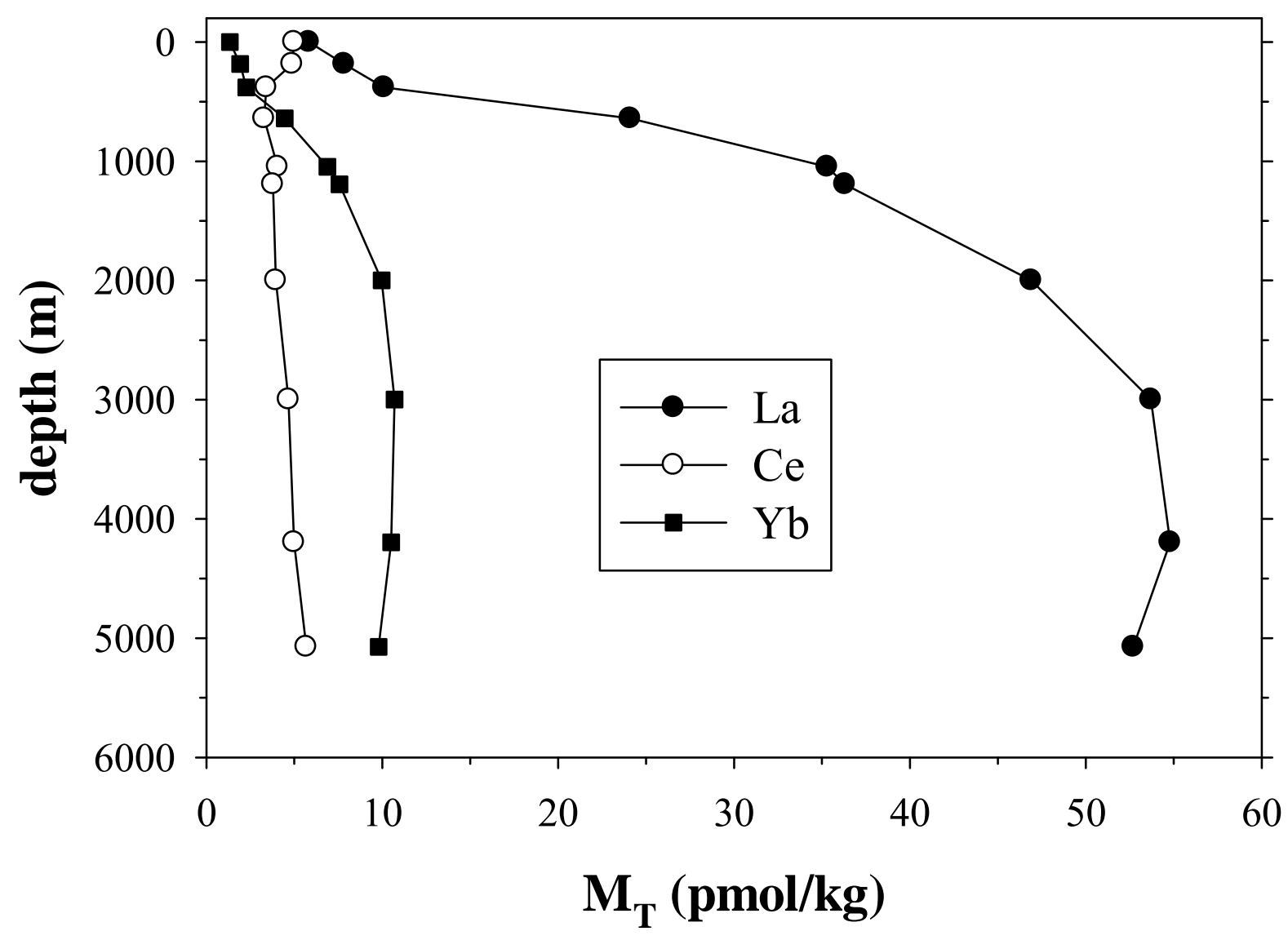

Figure 1. Vertical profiles of total dissolved YREE concentrations, $M_{\mathrm{T}}$, at station TPS 24 271-1 in the western Pacific Ocean (Piepgras and Jacobsen, 1992). Seawater was acidified but not filtered prior to ID-TIMS analysis. The anomalous behavior of cerium (Ce), caused by its unique redox chemistry, clearly contrasts with that of the strictly trivalent YREEs, represented by the light element lanthanum (La) and the heavy element ytterbium (Yb). 


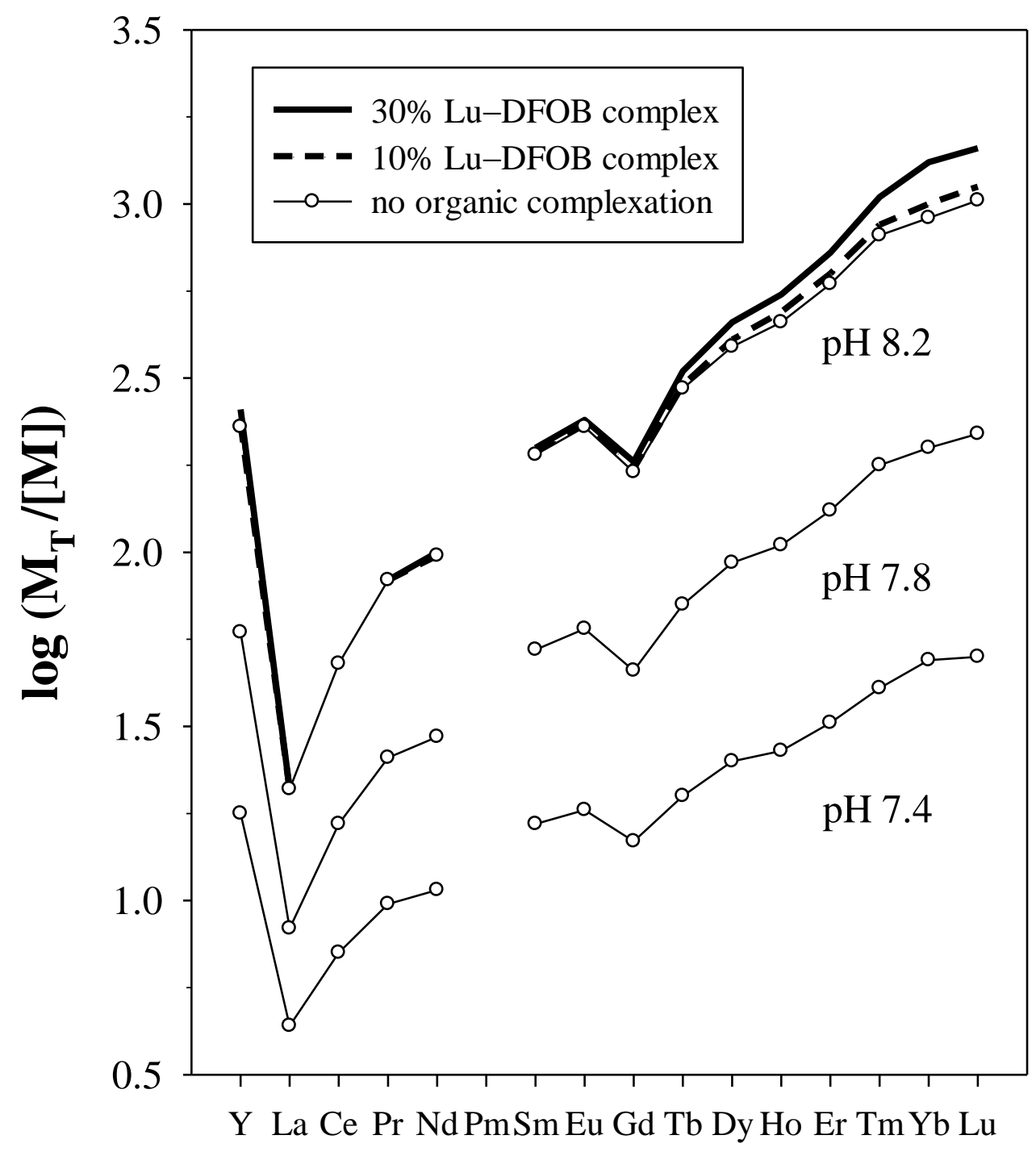

Figure 2. Ratio of total and free dissolved YREE concentrations in seawater $\left(\log M_{T} /[M]\right)$, the first term on the right-hand side of Eq. 9, derived from MINEQL calculations of YREE solution speciation in the presence of inorganic ligands only, at different $\mathrm{pH}$ (total scale). Results for $\mathrm{pH}$ 8.2 are listed in Table 3. Bold curves illustrate the effect of YREE complexation with strong organic ligands, represented by the model siderophore DFOB. The free concentration of the $\mathrm{HL}^{2-}$ species was fixed at levels that yield $10 \%$ and $30 \%$ contributions of the organic complex for $\mathrm{Lu}$ (see text). Below pH 8.2 DFOB quickly protonates, diminishing its influence. 


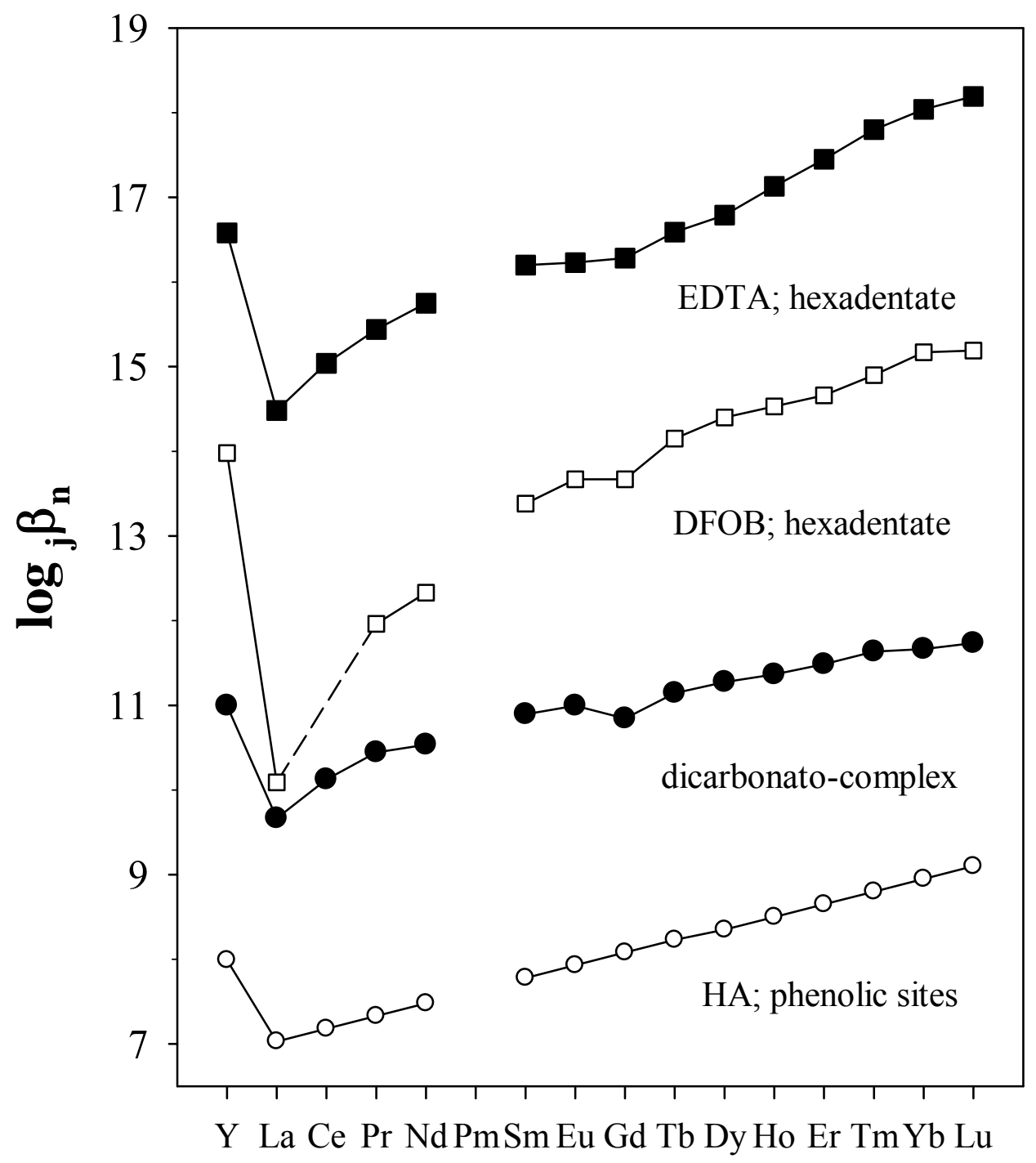

Figure 3. Stability constants $(I=0.7)$ for YREE complexes with two carbonate anions, the strongest inorganic ligand in seawater, and for hexadentate DFOB complexes (Table 2). Stability constants for Ce-DFOB complexes could not be measured (Christenson and Schijf, 2011). Also shown are stability constants $(I=0.5)$ for hexadentate EDTA complexes (Martell et al., 2004) and intrinsic constants for YREE binding to strong (type $\mathrm{B}=$ phenolic) sites of terrestrial humic acids (HA), converted as indicated by Sonke (2006) from his recommended values of $\mathrm{pK}_{\text {МнA. }}$. 


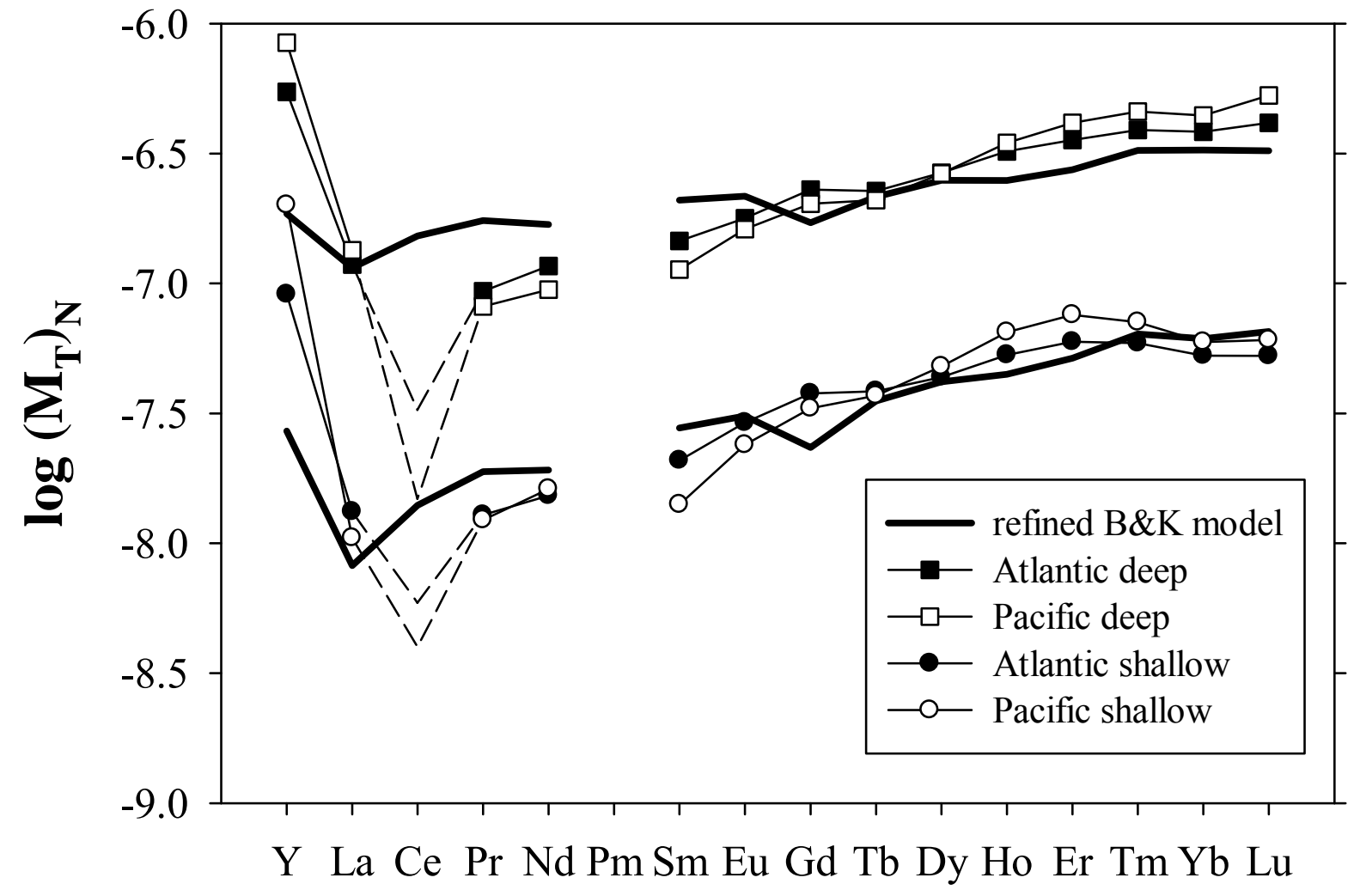

Figure 4. Patterns of shale-normalized total dissolved YREE concentrations, $\left(\mathrm{M}_{\mathrm{T}}\right)_{\mathrm{N}}$, for shallow and deep seawater samples from the Atlantic Ocean (station 162-1, 70 and 4033 m; Osborne et al., 2015) and the Pacific Ocean (station SA-12, 74 and 3936 m; Zhang and Nozaki, 1996). normalized to Post-Archaean Australian Shale (PAAS) (McLennan, 1989). See the references for station locations and other details. Bold curves are input-normalized abundance patterns for seawater predicted by the refined B\&K model, expanded to include $\mathrm{Y}$ and using $\log \overline{\mathrm{K}}_{\mathrm{S}}$ values recalculated with stability constants from the NIST database (Martell et al., 2004). Model curves for the shallow and deep samples, based on YREE solution speciations at $\mathrm{pH} 8.2$ and 7.6, respectively (Fig. 2), were vertically shifted to maximize overlap with the average shallow and deep seawater patterns, as described in the text. 

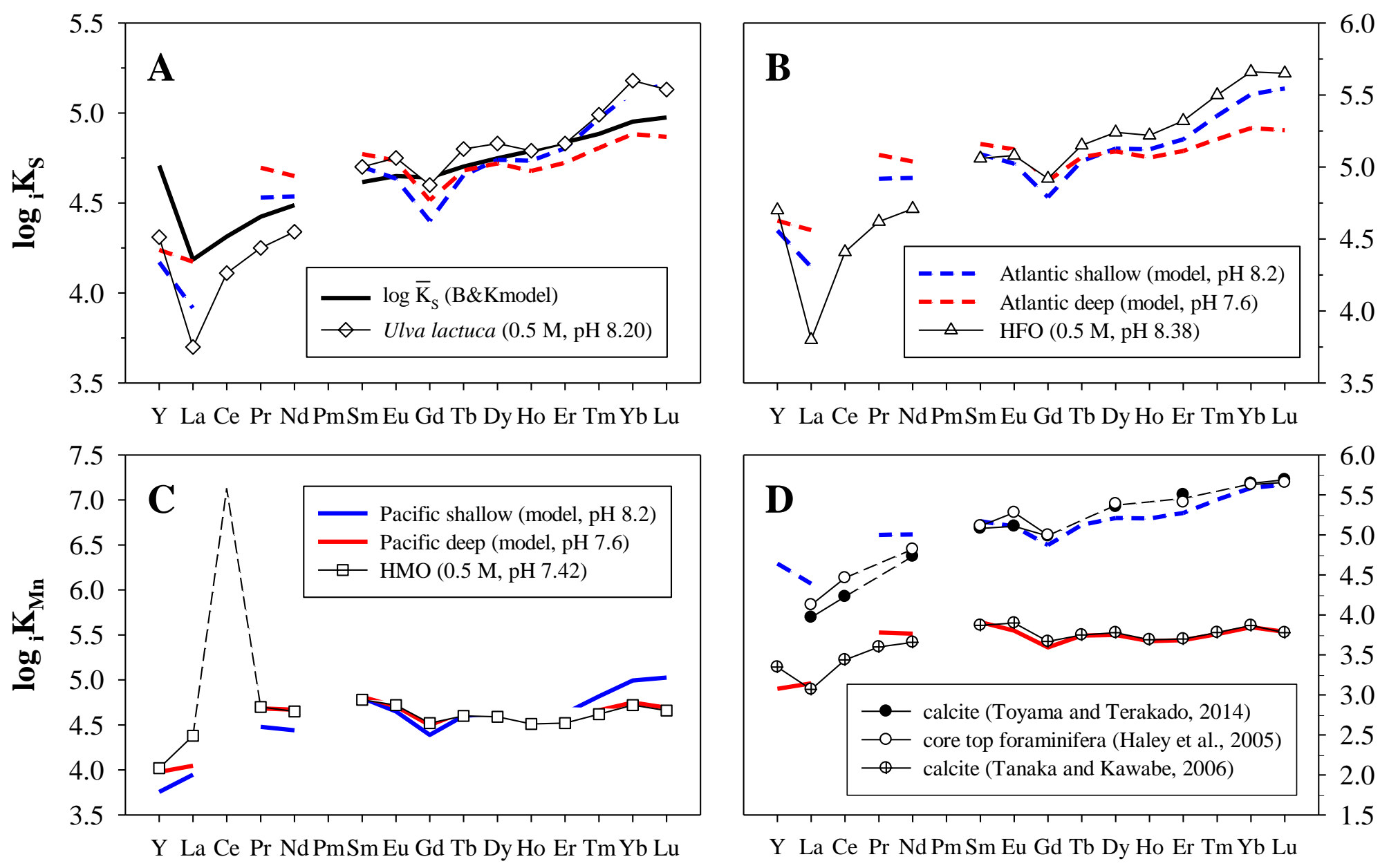

Y La Ce Pr NdPmSm Eu Gd Tb Dy Ho Er Tm Yb Lu

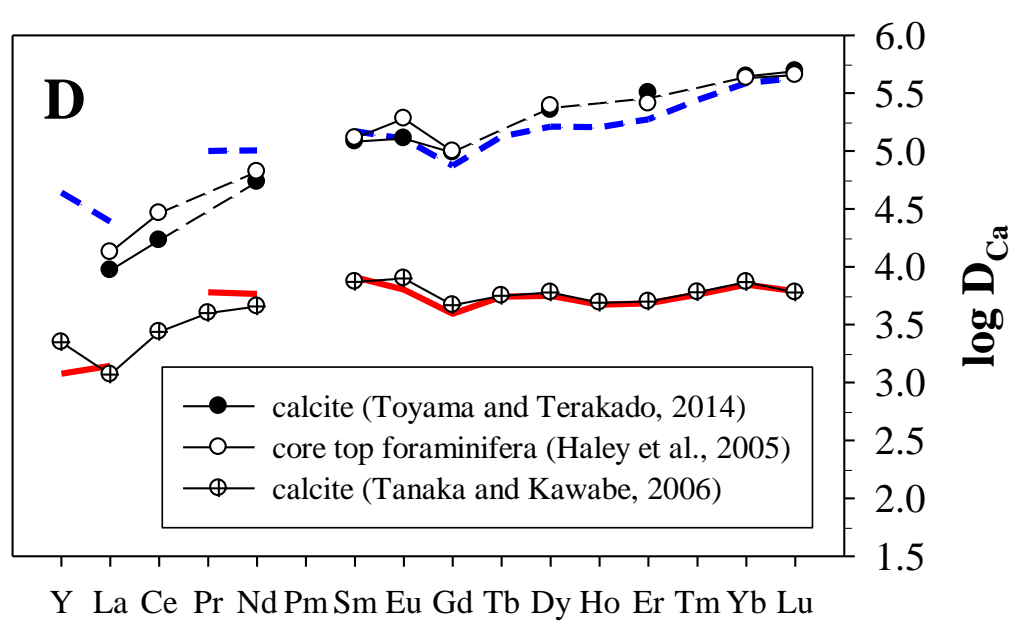

Figure 5. Comparison of the inverted scavenging model with distribution coefficients for YREE sorption on (A) Ulva lactuca (Zoll and Schijf, 2012); (B) hydrous ferric oxide (HFO) (Schijf and Marshall, 2011); (C) hydrous manganese oxide (HMO) (K.S. Marshall, unpubl. data); and (D) synthetic calcite and planktic foraminiferal calcite (N. dutertrei). Panel A also shows $\log \overline{\mathrm{K}}_{\mathrm{S}}$ as defined by Byrne and Kim (1990). Colored model curves (legends in B and C) are the same in all four panels, except for vertical shifts to maximize overlap with the distribution coefficient patterns. Only the best-matching model curves for shallow and deep seawater are shown in each panel. 

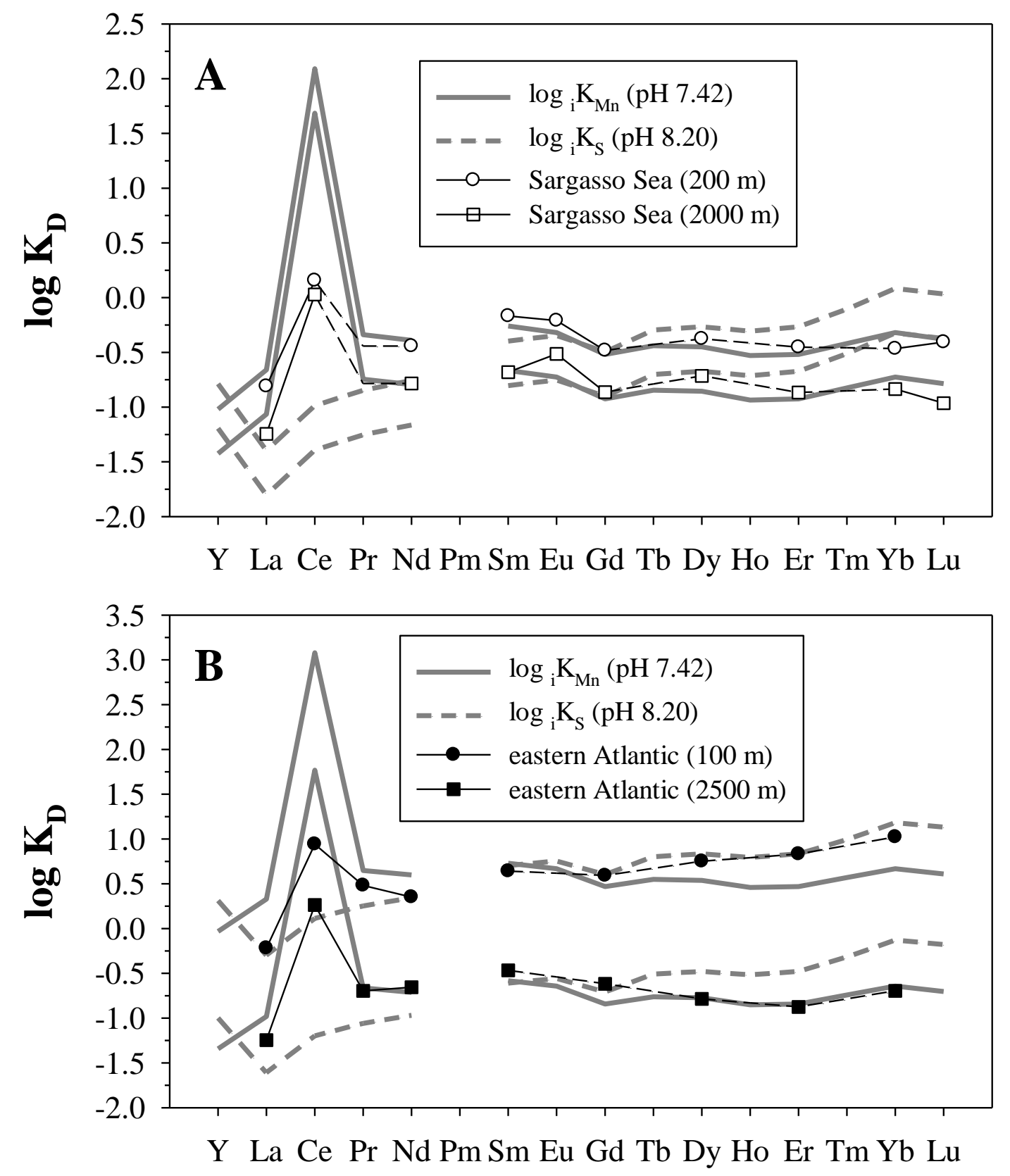

Figure 6. Comparisons of $\log _{\mathrm{i}} \mathrm{K}_{\mathrm{Mn}}$ and $\log _{\mathrm{i}} \mathrm{K}_{\mathrm{S}}$, the distribution coefficients for YREE sorption on HMO (K.S. Marshall, unpubl. data) and Ulva lactuca (Zoll and Schijf, 2012), respectively, with measured distribution coefficients for suspended particles from (A) the Sargasso Sea, leached with 25\% acetic acid (Sholkovitz et al., 1994); and (B) a mesotrophic station in the eastern Atlantic Ocean (Tachikawa et al., 1999b), corrected for detrital contributions by means of REE/Al ratios. Particulate concentrations were normalized to ambient seawater. The $\log _{\mathrm{i}} \mathrm{K}_{\mathrm{Mn}}$ and $\log _{i} \mathrm{~K}_{\mathrm{S}}$ curves were vertically shifted to maximize overlap with the particle patterns. 


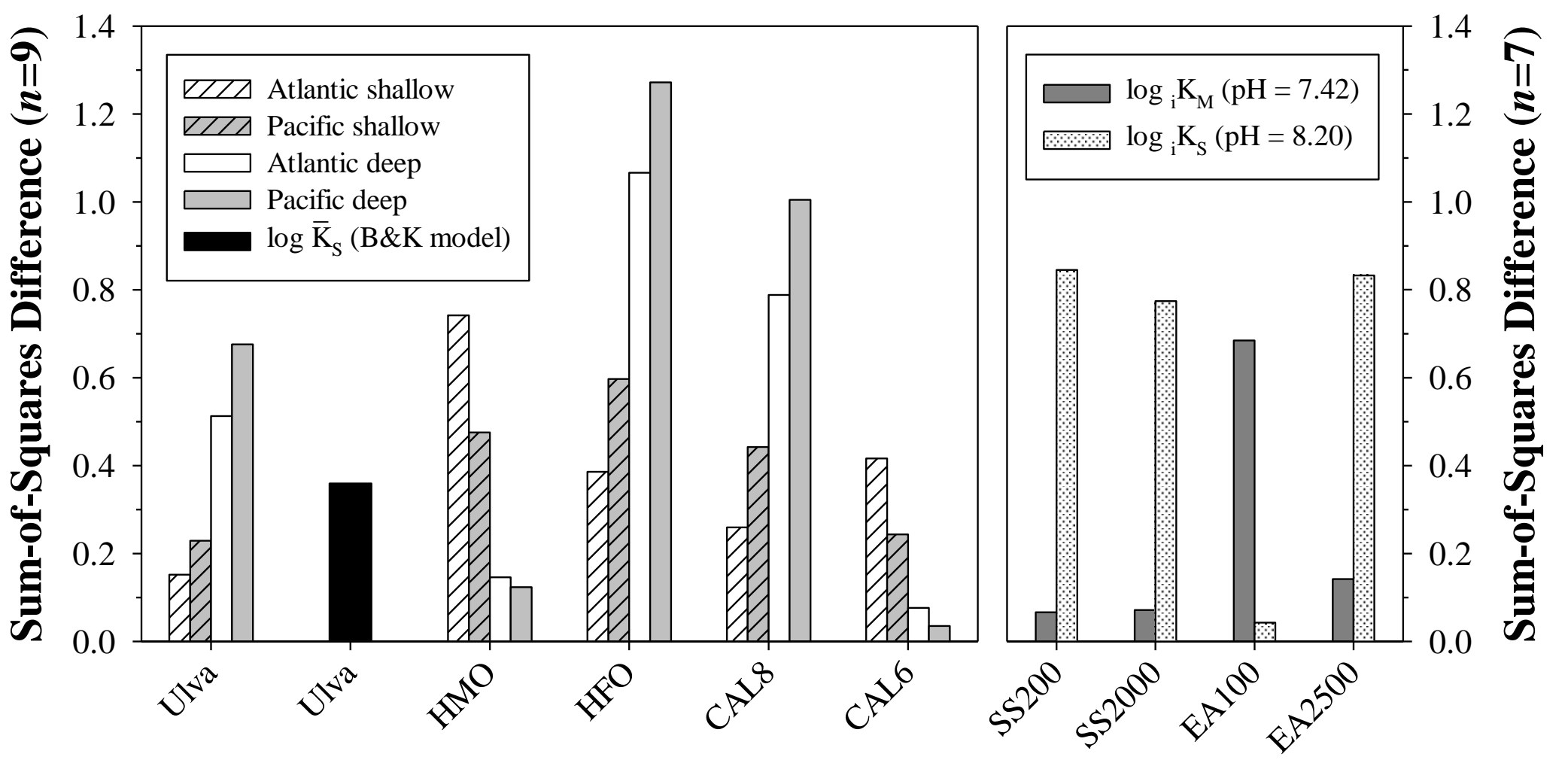

Figure 7. Sum-of-squares difference for pairwise comparisons of distribution coefficients for relevant solid phases with all Atlantic and Pacific model curves, some of which are shown in Figure 5 (left panel), and for all comparisons shown in Figure 6 (right panel). Lower values signify better agreement. Bar color and shading (see legend) correspond to one member of each pair and x-axis labels to the other. Summation was performed over a total of $n$ elements shared by all pairs (excluding Y and Ce). Values in the left panel should not be compared with those in the right panel, because they were summed over different elements. CAL8 is the average of data from Toyama and Terakado (2014) at $\mathrm{pH} \sim 8.45$ and from Haley et al. (2005), while CAL6 are data from Tanaka and Kawabe (2006) at pH 6.6 (Fig. 5D). SS and EA are suspended particles from the Sargasso Sea (Sholkovitz et al., 1994) and the eastern Atlantic Ocean (Tachikawa et al., 1999b), respectively, at the indicated depths (Fig. 6). 